\title{
Endophytic Fungi as Novel Resources of natural Therapeutics
}

\author{
Maheshwari Rajamanikyam ${ }^{1}$, Varahalarao Vadlapudi ${ }^{1 *}$, Ramars amanchy ${ }^{1}$, \\ Suryanarayana Murty Upadhyayula ${ }^{1,2} *$. \\ ${ }^{1}$ Biology Division, CSIR-Indian Institute of Chemical Technology (IICT), Uppal Road, Tarnaka, Hyderabad -500 \\ 007, India. ${ }^{2}$ National Institute of Pharmaceutical Education and Research (NIPER), Guwahati Medical College \\ Campus, Narakasur Hills Top, Guwahati -782032, India.
}

\begin{abstract}
Fungal endophytes constitute a major part of the unexplored fungal diversity. Endophytic fungi (EF) are an important source for novel, potential and active metabolites. Plant-endophyte interaction and endophyte-endophyte interactions study provide insights into mutualism and metabolite production by fungi. Bioactive compounds produced by endophytes main function are helping the host plants to resist external biotic and abiotic stress, which benefit the host survival in return. These organisms mainly consist of members of the Ascomycota, Basidiomycota, Zygomycota and Oomycota. Recently, the genome sequencing technology has emerged as one of the most efficient tools that can provide whole information of a genome in a small period of time. Endophytes are fertile ground for drug discovery. EFare considered as the hidden members of the microbial world and represent an underutilized resource for new therapeutics and compounds. Endophytes are rich source of natural products displaying broad spectrum of biological activities like anticancer, antibacterial, antiviral, immunomodulatory, antidiabetic, antioxidant, anti-arthritis and anti-inflammatory.
\end{abstract}

Key words: Endophytic fungi, Ascomycota, Natural products, Antidiabetic.

\footnotetext{
*Author for correspondence: vvraophd@gmail.com
} 


\section{INTRODUCTION}

Endophytic fungi $[\mathrm{EF}]$ are organisms which live in all healthy plant tissues without signs of disease or morphological changes for at least part or the whole life cycle of the plant $\left[{ }^{1}\right]$. The existence of fungi inside the plants has been known since the end of the 19th century, and the term "endophyte" was first coined in 1866 by de Bary. EF has been associated with plants for over 400 million years $\left.{ }^{2}\right]$. An endophytic fungus lives in mycelial form in biological association with the living plant. EF are found in all kinds of plants, i.e. trees, grasses, algae and herbaceous plants. Endophyte and endophytic fungi have been frequently used to describe the internal mycota of living plants. EF are now considered as an important components of biodiversity $\left[{ }^{3,4}\right]$.EF are highly diverse, with the reported majority being ascomycetes, also lack a of teleomorphic state $\left[^{5}\right]$. In one survey it is estimated that over one million fungal endophytes exist in nature $\left[{ }^{6}\right]$. $\mathrm{EF}$ is an important source of novel, potential and active metabolites $\left[^{7-12}\right]$. Bioactive compounds produced by EF main function are helping the host plants to resist external biotic and abiotic stress, which benefit the host survival in return. Plants lack immune response to certain pathogens, but the endophytes that reside inside the plant tissue enhance the immune response of the plants to fight against invading pathogens $\left[{ }^{13}\right]$. Plant EF has the ability to produce the same or similar kind of compounds of from their originated host plants. Fungal endophyte communities differ in species composition, host and tissue preference worldwide distribution and differ in the polyketide and synthesis and production of bioactive compounds $\left[{ }^{14}\right]$. In the last few years, considerable knowledge has been accumulated on the biology of endophytic microorganisms $\left[{ }^{15}\right]$. The study of endophytes distribution, biodiversity and their biochemical characteristics has huge importance in plant sciences to understand and to improve plant fitness $\left[{ }^{16}\right]$. Endophytes commonly increase plant biomass under stressful conditions but the cellular mechanisms involved in stress tolerance and growth enhancement are poorly characterized. $\mathrm{EF}$ are considered as an important components of biodiversity as the distribution of endophytic mycoflora differs with the host. The omnipresence of endophytic fungi symbiosis with the plant, the extent of their contribution to fungal biodiversity remains unclear $\left[{ }^{17}\right]$. Apart from the above mentioned myriad of activities for the protection of host plants EF play an important role to initiate the biological degradation of dead or dying host-plant, which is necessary for nutrient recycling. The "balanced antagonism" hypothesis $\left[{ }^{18}\right]$ was initially proposed to address how an endophyte controls host defenses mechanisms to be activated against it, ensures self-resistance before being incapacitated by the toxic metabolites of the host, and manages to grow within its host without causing visible manifestations of infection or disease $\left[{ }^{19,20}\right]$.

\section{Plant-endophyte interaction}

How does an endophyte manage to exist and grow within its host without causing visible disease symptoms? Is a complex and precisely controlled interaction. Endophyte-plant symbioses represent a broad continuum of interactions, from strong antagonisms to obligate mutualisms. Mutualisms are generally thought to have evolved from antagonistic interactions, mainly parasitic and the same has been assumed for fungal endophytes of grasses and woody plants. The continuum of antagonistic-mutualistic interactions for any two interacting species depends on phylogenetic and life history constraints, geography, interactions with other species in the community, and abiotic factors. Similarly, the complex microbial mutualisms with host plants vary along a continuum from pathogenic to mutualistic, even within the lifespan of the microorganism and host plant. Despite 
the complexity and variability of EF-host plant interactions, evolutionary traits, Modes of reproduction and transmission to other hosts are now well recognized as important factors related to virulence and aggressiveness in disease-causing microorganisms - and ecological factors - such as condition of host, competition with other microorganisms, spatial structure of populations, and prevailing abiotic factors - permit predictions of where endophyte-plant associations are likely to fall along the continuum. Endophytes reside within plants and are continuously interacting with their hosts; it is conceivable that plants would have a substantial influence on the in plant metabolic processes of the endophytes. Although it has long been known that fungal secondary metabolites are crucial to the pathogenicity of many fungi only little experimental work has been done to study the role of secondary metabolites in the endophyte-host interaction. There are several physiological mechanisms of the endophyte-host interaction well understood and established but mechanisms that gave rise to the evolution of endophytism and the genetic basis of the endophytic habit are also poorly understood. It has been speculated that endophytic lineages have evolved several times from plant pathogenic ancestors. The 'endophytic continuum' model suggests that the outcome of the plant- fungus interaction which can range from mutualism to parasitism depends on the fungal species, the host genetic background and the environment.

\section{Endophyte -Endophyte interactions}

Many recent studies provide evidence that microbial interactions can play a major role in the onset of metabolite production in fungi and which may involve small, diffusible signalling molecules, such as quorum-sensing signals or other elicitors, which may trigger otherwise silent biosynthetic pathways. In microbial communities, potentially every natural product could have an impact on the metabolic profiles of the microorganisms sharing the same habitat. In endophytic communities, potentially every natural product could have an impact on the metabolic profiles of these microorganisms sharing the same habitat. The interesting fact is that, the interplay between endophytes within the plant results in significantly higher natural product diversity than what is observed in organism as individual. To study the communication and interaction between Endophyte -Endophyte we need emerging tools. Systems biology uses a multidisciplinary approach to study the multiple, complex interactions of and between organisms. The endophyte-endophyte differential gene expression can be revealed using various tools like suppression subtractive hybridization $(\mathrm{SSH})$ technique, serial analysis of gene expression (SAGE), cap analysis of gene expression (CAGE) and massive parallel signature sequencing (MPSS).

\section{General Classification}

Endophytic fungi mainly consist of members of the Ascomycota $\left[{ }^{21}\right]$ or their mitosporic fungi, as well as some taxa of the Basidiomycota, Zygomycota and Oomycota $\left[{ }^{22,23}\right]$ and Classification endophytic fungi and existence in plant cell (Fig.1). But there are also different ways of grouping fungal endophytes are suggested by $\left[{ }^{24}\right]$ the transmission mode in particular, and distinguished between the endophytes of the Clavicipitaceae (clavicipitaceous endophytes) and the rest (non-clavicipitaceous endophytes). Several studies have demonstrated that various fungal endophytic interactions ranging from mutualistic to antagonistic, depending on host and endophyte genotype, and environmental conditions $\left[{ }^{25-29}\right]$. 


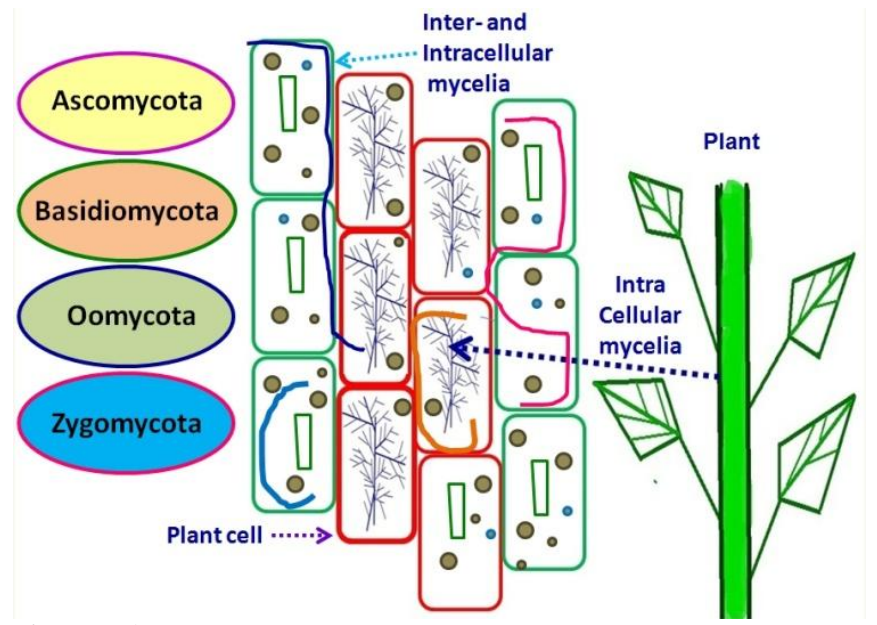

Figure. 1- Classification of endophytic fungi and existence in plant cell

\section{Molecular studies and Phylogeny}

Fungal taxonomy is traditionally based on comparative morphological features $\left.{ }^{[30,31}\right]$ but need take special caution for closely related or morphologically similar species. Mycologists facing tough task for to identify various EF at genera or species level because they mainly depends only on morphological characteristics and also very time-consuming process. More over significant portions of endophytic isolates consist of sterile mycelia and cannot be identified based on traditional approaches. The development of molecular biology brings a new perspective to endophyte diversity studies. Modern molecular techniques exhibit high sensitivity and specificity for identifying and classifying microbial strains at diverse hierarchical taxonomic levels $\left[{ }^{32}\right]$. Many phylogenetic studies involving fungi rely on the analysis of ribosomal DNA, in particular the internal transcribed spacer (ITS) regions, to assist in separation at the genus and species levels $\left[{ }^{33}\right]$. $18 \mathrm{~S}$ and $28 \mathrm{~S}$ genes are considered as identification markers in the identification of $\mathrm{EF}$ at high taxonomic levels $\left[{ }^{34}\right]$. The recently developed, high-throughput sequencing (pyrosequencing) enables metagenomic and metagenetic analyses and provides a powerful alternative to molecular studies of fungal community in natural environments $\left[{ }^{35}\right]$. Pyrosequencing has several advantages like inexpensive, rapid, free-cloning step and high productivity over Sanger sequencing technology $\left.{ }^{36}\right]$. This technique has been employed successfully in the study of fungal diversity in natural environments, such as phyllosphere fungi $\left[{ }^{37}\right]$, clinical fungi $\left[{ }^{38}\right]$, freshwater fungi $\left[{ }^{39}\right]$, wood-inhabiting fungi $\left[{ }^{40}\right]$, soil fungi $\left[{ }^{4}\right]$ and mycorrhizal fungi $\left[{ }^{42}\right]$. DNA barcoding systems employ a short, effective and standardized gene region to identify species $\left[{ }^{43}\right]$. This method is advanced for screening of fungal endophytes, ideally, the DNA barcode region used should be a single locus for all groups of organisms across all kingdoms. ITS based DNA barcode approaches has many advantages, such as high successful amplification among all lineages of EF using universal primers, suitable fragment length, and a large number of available databases $\left[{ }^{44,45}\right]$. There are several disadvantages too in using ITS barcode like there are various inter- and intra-specific distances among the different fungal groups. There is another method which is cheap and fast simple sequence repeat (SSR) marker technique. A number of previous studies have demonstrated that ITS is insufficient for some species delimitation, especially in rapidly evolving or highly diverse genera $\left[{ }^{46}\right]$.Denaturing gradient gel electrophoresis (DGGE) technique, which are capable of separating closely related sequences by their differential mobilities in a gradient of denaturants, have recently been successfully applied to document endophytic fungal 
Novel resource and potential of endophytic fungi

communities by excising and sequencing bands $\left[{ }^{47,}{ }^{48}\right]$. (Table.1) list of endophytes isolated from host plant using Phylogeny analysis.

Table-1- list of endophytes isolated from host plant using Phylogeny analysis

\begin{tabular}{|c|c|c|}
\hline Entophyte & Host plant & Ref \\
\hline Muscodor albus & Cinnamomum zeylanicum & {$\left[{ }^{49}\right]$} \\
\hline $\begin{array}{l}\text { Alternaria, Cladosporium, Chaetomium, Curvularia, } \\
\text { Drechslera, Scopulariopsis,Acremonium, Aspergillus, C } \\
\text { olletotrichum, Fusarium, Paecilomyces,Penicillium. }\end{array}$ & Glycine max & {$\left[{ }^{50}\right]$} \\
\hline $\begin{array}{l}\text { Alternaria sp., Colletotrichum sp., Phomopsis sp., } \\
\text { Xylaria sp., }\end{array}$ & $\begin{array}{l}\text { Artemisia capillaris, } A . \\
\text { indica, and A. lactiflora }\end{array}$ & {$\left[{ }^{51}\right]$} \\
\hline $\begin{array}{l}\text { Cladosporium sp., Acremonium sp., Trichoderma sp., } \\
\text { Monilia sp., Fusarium sp., Spicaria sp., Humicola sp., } \\
\text { Rhizoctonia sp., Cephalosporium sp., Botrytis sp., } \\
\text { Penicillium sp., Chalaropsis sp. and Geotrichum sp., }\end{array}$ & Cephalotaxus mannii & {$\left[{ }^{52}\right]$} \\
\hline Fusarium solani & Taxus baccata & {$\left[{ }^{53}\right]$} \\
\hline Stemphylium sedicola $S B U-16$ & Taxus baccata & {$\left[{ }^{54}\right]$} \\
\hline Fusarium sp., Nectria rigidiuscula & Annona squamosa & {$\left[{ }^{55}\right]$} \\
\hline Fusarium oxysporum, Emericella nidulans & Ipomea batatas & {$\left[{ }^{56}\right]$} \\
\hline Paraconiothyrium sp & $\begin{array}{l}\text { Capsicum } \quad \text { annuum, } \\
\text { Cucumis sativus, Glycine } \\
\text { max }\end{array}$ & {$\left[{ }^{57}\right]$} \\
\hline $\begin{array}{l}\text { Phomopsis sp.,, Diaporthe sp.,, Dothideomycete sp., } \\
\text { Cordyceps sp., }\end{array}$ & Trichilia elegans & {$\left[{ }^{58}\right]$} \\
\hline $\begin{array}{l}\text { Alternaria sp., Cladosporium sp., Curvularia sp., } \\
\text { Fusarium sp., Phaeoacremonium sp., Trichoderma sp., }\end{array}$ & Aquilaria malaccensis & {$\left[{ }^{59}\right]$} \\
\hline Trichoderma sp., & Coffea arabica & {$\left[{ }^{60}\right]$} \\
\hline Trichothecium sp., & Phyllanthus amarus & {$\left[{ }^{61}\right]$} \\
\hline $\begin{array}{l}\text {,Glomerella spp.,Diaporthae/Phomopsis sp., Alternaria } \\
\text { spp., } \\
\text { Emericella sp., }\end{array}$ & $\begin{array}{l}\text { Aegle marmelos, Coccinia } \\
\text { indica, Moringa oleifera }\end{array}$ & {$\left[{ }^{62}\right]$} \\
\hline $\begin{array}{l}\text { Acremonium sp., Colletotrichum sp., Cochliobolus sp., } \\
\text { Fusarium, Hypocrea sp., Nemania sp. }\end{array}$ & Lycium chinense & {$\left[{ }^{63}\right]$} \\
\hline $\begin{array}{lcccc}\text { Colletotrichum } & s p ., \quad \text { Curvularia } & \text { sp., Fusarium } & \text { sp., } \\
\text { Phomopsis } & s p ., & \text { Verticillium } & \text { sp., } \\
\text { Fusarium sp., Phomopsis sp. } & & & \\
\end{array}$ & $\begin{array}{l}\text { Tabernaemontana } \\
\text { heyneana }\end{array}$ & {$\left[{ }^{64}\right]$} \\
\hline Alternaria sp., Phomopsis magnoliae & Artemisia argyi. & {$\left[{ }^{65}\right]$} \\
\hline Acremonium $s p .$, Penicillium $s p$. & Gossypium hirsutum & {$\left[{ }^{66}\right]$} \\
\hline Trichoderma brevicompactum & Allium sativum & {$\left[{ }^{67}\right]$} \\
\hline $\begin{array}{l}\text { Sporidiobolus sp., Rhodotorula sp., Pilidium concavum, } \\
\text { Corynespora cassiicola, Neodeightonia subglobosa, } \\
\text { Aspergillus awamori, Aspergillus sp. }\end{array}$ & Fragaria $x$ ananassa & {$\left[{ }^{68}\right]$} \\
\hline Epichlö festucae & Festuca rubra & {$\left[{ }^{69}\right]$} \\
\hline Pestalotiopsis fici & Camellia sinensis & {$\left[{ }^{70}\right]$} \\
\hline $\begin{array}{l}\text { Aspergillus niger, Bipolaris maydis, Meyerozyma } \\
\text { guilliermondii, Fusarium verticillioides }\end{array}$ & Ocimum sanctum & {$\left[{ }^{71}\right]$} \\
\hline $\begin{array}{l}\text { Aspergillus sp., Penicillium sp., }{ }^{2} \text { Unidentified } \\
\text { Eurotiomycete belong to Eurotiomycetes sp., } \\
\text { Acremonium sp., Colletotrichum sp., Fusarium sp., } \\
\text { Nodulisporium sp., Pestalotiopsis }\end{array}$ & Marchantiapolymorpha & {$\left[{ }^{72}\right]$} \\
\hline $\begin{array}{l}\text { Fusarium proliferatum, Fusarium sp., } F . \quad \text { solani, } \\
\text { Curvularia lunata, Trichoderma atroviride, Calonectria } \\
\text { gracilis, Rhizoctonia solani, Bionectria ochroleuca }\end{array}$ & Musa acuminata & {$\left[{ }^{73}\right]$} \\
\hline $\begin{array}{l}\text { Penicillium chrysogenum, P. chrysogenum, Fusarium } \\
\text { oxysporum, F. nygamai }\end{array}$ & $\begin{array}{l}\text { Tamarix nilotica, Cressa } \\
\text { cretica }\end{array}$ & {$\left[{ }^{74}\right]$} \\
\hline
\end{tabular}




\begin{tabular}{|c|c|c|}
\hline $\begin{array}{l}\text { Diaporthe sp.,, Colletotrichum sp.,, Nigrospora sp., } \\
\text { Botryosphaeria sp., Aspergillus sp., Penicillium sp., } \\
\text { Neofusicoccum sp., Cercospora sp., Rhizoctonia sp., } \\
\text { Alternaria sp., Curvularia sp., }\end{array}$ & $\begin{array}{l}\text { Artemisia lavandulifolia, } A . \\
\text { tangutica, A. brachyloba, A. } \\
\text { subulata, A. argy A. } \\
\text { scoparia }\end{array}$ & {$\left[{ }^{75}\right]$} \\
\hline Penicillium polonicum & Huperzia serrata & \\
\hline Diaporthe ampelina & Commiphora wightii & \\
\hline Emericella qaudrilineata (RS-5): & Pteris pellucida & {$\left[{ }^{78}\right]$} \\
\hline Chaetomium globosum & Nymphaea nouchali & {$\left[{ }^{79}\right]$} \\
\hline $\begin{array}{l}\text { Aspergillus sp., Chaetomium sp., } \text { Curvularia sp., } \\
\text { Dreschelara sp., Fusarium sp., Penicillum sp., } \\
\text { Colletotrichum sp., Nigrospora sp., Pestalotiopsis sp. } \\
\text { and Phyllosticta sp. }\end{array}$ & Hugonia mystax & {$\left[{ }^{80}\right]$} \\
\hline Aspergillus nidulans, Aspergillus oryzae. & Ginkgo biloba & {$\left[{ }^{81}\right]$} \\
\hline Phomopsis theicola & Litsea hypophaea & {$\left[{ }^{82}\right]$} \\
\hline Fusarium sp., & Honeysuckle & {$\left[{ }^{83}\right]$} \\
\hline Aspergillus flavus & Solanum nigrum & {$\left[{ }^{84}\right]$} \\
\hline Pestalotiopsis clavispora, & Dendrobium officinale & {$\left[{ }^{85}\right]$} \\
\hline Trichoderma-Hypocrea, Penicillium Phialemonium. & Balanophora japonica & {$\left[{ }^{86}\right]$} \\
\hline $\begin{array}{l}\text { Trichoderma sp., Aspergillus sp., Rhizopus } \\
\text { Cladosporium sp., } \\
\text { Chepalosporium sp. }\end{array}$ & Toona sinensis & {$\left[{ }^{87}\right]$} \\
\hline $\begin{array}{l}\text { Cladosporium cladosporioides, Aspergillus ochraceus, } \\
\text { Aspergillus niger, Aspergillus flavus, Penicillium } \\
\text { citrinum, Monascus ruber, Fusarium semitectum, } \\
\text { Fusarium sp., Fusarium sp. }\end{array}$ & Corn cob & {$\left[{ }^{88}\right]$} \\
\hline Fusarium solani & $\begin{array}{l}\text { Phaius tankervilleae, } \\
\text { Dendrobium lancifolium, } \\
\text { Calanthe triplicata }\end{array}$ & {$\left[{ }^{89}\right]$} \\
\hline Talaromyces amestolkiae & Kandelia obovata & {$\left[{ }^{90}\right]$} \\
\hline
\end{tabular}

\section{Proteomic analysis}

Proteins secreted by fungal hyphae play an important role in the plant cell during symbiosis these molecules used in establishing and maintaining a successful symbiotic relationship among them. Proteomics appears as a powerful tool (Fig.2) to gain a global picture and our perception of plant-microbe interactions. 2-Dimentional Electrophorisis (2-DE) is a tool used to compare infected and noninfected plant proteomes it also provides a way of identifying plant and fungal proteins differentially regulated in this symbiosis [91]. Proteins were extracted from Undifilum oxytropis and analysed using 2-DE and liquid chromatography tandem mass spectrometry (LC-MS/MS) $\left[{ }^{92}\right]$ and found large group proteins were related to stress and heat shock proteins. EST-based approach was used for identification of proteins from filamentous fungal endophyte based on $\left[{ }^{93}\right]$. Protein extraction was followed according to $\left[{ }^{94}\right]$ and further 2-DE analysis was done for the proteins of Piriformospora indica $\left[{ }^{95}\right]$.

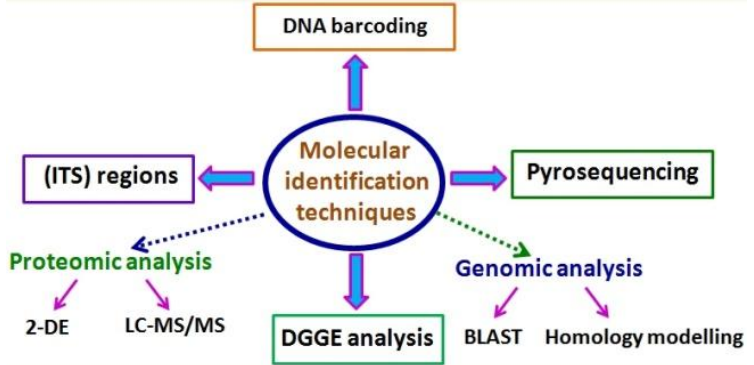

Figure. 2- Proteomic and genomic tools for analysis of endophytic fungi 


\section{Genomic analysis}

The field of fungal genomics and with that of eukaryotic genomics, started with the report on the complete sequence of the yeast $S$. cerevisiae $\left[{ }^{96}\right]$. Recently, the genome sequencing technology has emerged as one of the most efficient tools that can provide whole information of a genome in a small period of time. Identification of genes expressed during different phases of endophytism such as pre-penetration, plant tissue penetration and plant colonization is important task for the fungal genomics. The rapid development in molecular biology and genomics in the recent advances offers a lot of scope for unraveling the various facets of the ecology and phylogenetics for the horizontally transmitted endophytes. Now a day's Genomic analysis was done by BLAST search, Homology modeling tools.

\section{Fungal sources as natural products}

Endophytes constitute a major part of the unexplored fungal diversity. Natural products derived particularly from medicinal plants have been exploited for human use for thousands of years to make human life easy. Endophytes are fertile ground for drug discovery. Establishment of fungal repositories from various ecological niches is an important step towards tapping their potential values for novel drug discovery. EF are considered as the hidden members of the microbial world and represents an underutilized resource for new therapeutics and compounds. Fungal Secondary metabolites are defined as low molecular weight compounds not required for growth but they are produced as an adaptation for specific functions in nature. There is an ongoing need for novel drugs that are highly effective in the treatment of cancer, drug resistant bacteria, and fungal infections. Reviews, patents, and original research articles on isolation and identification of metabolites from EF are rapidly growing in this modern field of drug discovery $\left[{ }^{97}\right]$.Recently, several studies have led to the discovery of important plant secondary metabolites from EF thus raising the prospect of using such organisms as alternative sources of these metabolites $\left[{ }^{98}\right]$.

Endophytes are rich source of natural products displaying broad spectrum of biological activities. They produce diverse groups of metabolites such as (Fig.3) steroids, xanthones, phenols, isocoumarines, perylene derivatives, quinones, furandiones, terpenoids, depsipeptides and cytochalasine, polyketides, alkaloids, peptides, proteins, lipids, shikimates, glycosides, isoprenoids $\left[{ }^{99}\right]$.The secondary metabolites produced by endophytes associated with medicinal plants can be exploited for curing many diseases. EF are a poorly investigated group of microorganisms that represent an abundant and dependable source of bioactive and chemically novel compounds. Several attempts have been made to isolate and identify various bioactive metabolites from endophytic fungi. EF can grow in small to large fermenters to provide sufficient supply of bioactive compounds and thus can be exploited commercially. Presently there is a huge potential for endophytes biologically active natural products which are useful not only in medical but extended to agricultural and industrial application. Now a day's these enzymes are used in energy, food, paper, textile, cosmetics, fine chemicals, biomaterials, leather, cellulose and detergent industries. Bioprospecting of microbes is carried out from every possible source, including extreme environments like ocean beds, geothermal vents, cold desserts etc., in search of novel strains with promising bioactivities $\left[{ }^{100,}{ }^{101}\right]$. Endophytes produce low molecular weight and volatile organic compounds (VOCs) $\left[{ }^{102}\right]$ such as alcohols, ketones, esters, acids, and hydrocarbons typically derived from either biosynthetic or degradative pathways. VOCs attracted interest for a variety of 
potential applications, including use as characteristic markers of fungal growth in the built environment (e.g., workspaces and residential structures) $\left[{ }^{103}\right]$ and volatile antibiotics $\left[{ }^{104,105}\right]$.

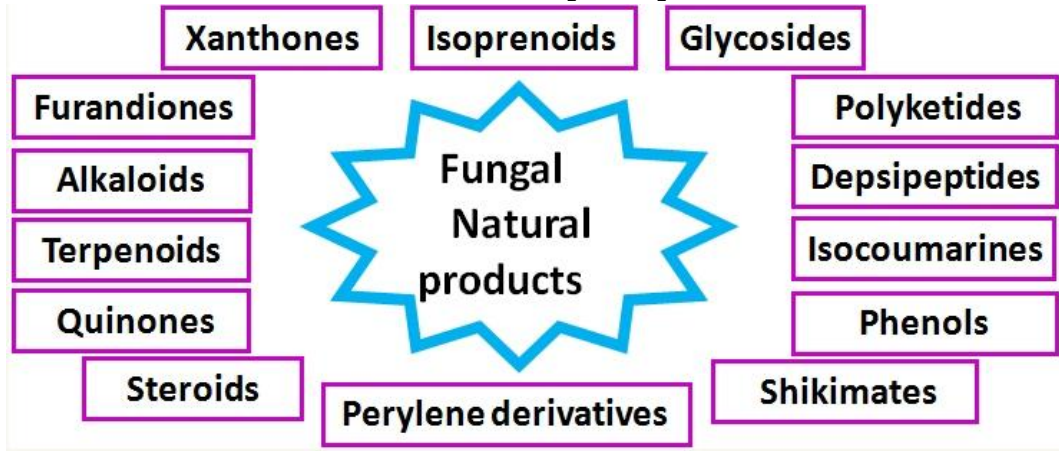

Figure. 3- Different groups of fungal metabolites

\section{Antibacterial substances of endophytic origin}

Emergence of multidrug-resistant (MDR) microorganism infections has generated considerable attention in recent decades $\left[{ }^{106,107}\right]$. The problem of drugresistant pathogens and infectious diseases are growing enormously. Antibiotic resistance is one of the greatest challenges facing modern medicine $\left[{ }^{108}\right]$. New problems demand the discovered of novel antibiotics from fungal source. Staphylococcus aureus (MRSA) and Vancomycin-resistant Enterococcus faecium (VREF), have developed resistance toward current antibiotics. Antibiotics that lose their effectiveness for treating human disease through antibiotic resistance in this scenario old therapeutics must be replaced with new drugs $\left[{ }^{109}\right]$.Metabolites produced from endophytes were reported to inhibit the growth of microorganisms in host. The world recognized that fungal endophytes with novel metabolites biologically active against various resistant human pathogens. The World Health Organization (WHO) estimated that one-third of the world's human population is infected with Mycobacterium tuberculosis (MT) $\left[{ }^{110}\right]$.Due to the emergence of multi-drug resistant of $M$. tuberculosis bacteria there is an urgent need to discover and develop new and non-toxic therapeutic agents from natural sources. Phomapyrrolidones A-C isolated from Phoma sp. NRRL 46751 showed antitubercular activity $\left[{ }^{111}\right]$. [ $\left.{ }^{112}\right]$ Isolated Alterporriol-type dimers from the mangrove endophytic fungus, Alternaria sp. (SK11) and the compound Atropisomer 2 exhibited strong inhibitory activity against MT. $\left[{ }^{113}\right]$ Investigated natural compounds from Annulohypoxylon ilanense of medicinal plant Cinnamomum species against MT. Recently, there have been an increasing number of articles on the research of EF producing antimicrobial substances $\left[{ }^{114}\right]$. Since the discovery of penicillin saved billions of lives and played an important role in human history. There are numerous reports on antimicrobial activity of EF isolated from various plant sources are presented in (Table.2).

Table-2- list of endophytes isolated from host plant against bacterial species

\begin{tabular}{|c|c|c|c|}
\hline Host plant & Endophyte & Target bacteria & Ref \\
\hline $\begin{array}{l}\text { Camptotheca } \\
\text { acuminata }\end{array}$ & $\begin{array}{l}\text { Nigrospora, Diaporthe, } \\
\text { Alternaria, } \\
\text { Colletotrichum, } \\
\text { Pestalotiopsis, } \\
\text { Sordariomycete, } \\
\text { Guignardiai, }\end{array}$ & $\begin{array}{l}P, \quad \text { solanacearum } \\
\text { Ralstonia solanacearum }\end{array}$ & {$\left[{ }^{115}\right]$} \\
\hline $\begin{array}{l}\text { Smallanthus } \\
\text { sonchifolius (yacón) }\end{array}$ & $\begin{array}{l}\text { Papulaspora } \\
\text { immersa and Arthrinium } \\
\text { state of Apiospora }\end{array}$ & $\begin{array}{l}S, \quad \text { aureus, Kocuria } \\
\text { rhizophila } P, \text { aeruginosa }\end{array}$ & {$\left[{ }^{116}\right]$} \\
\hline
\end{tabular}


Novel resource and potential of endophytic fungi

montagnei Sacc

Pichia guilliermondii

Paris polyphylla var. yunnanensis

Sesbania grandiflora (L.) Pers.,

Vitex negundo Linn,

Ricinus communis (Aurundi)

Achyranthes aspera, Adhatoda zeylanica, Aegle marmelos, Leucas aspera, Azadirachta indica
Fusarium sp,

Phaeoacremonium sp., Acremonium sp. Cladosporium $\mathrm{sp}$

Colletotrichum

gloeosporioides Penz.,

Phomopsis archeri B.

Sutton, A. flavus gr.,

Nigrospora

sphaerica(Sacc.)Mason,

Colletotrichum

gloeosporioides Penz.,

Phomopsis sp. aff. $P$.

archeri B. Sutton,

Alternaria raphani JW

Groves \&skolko, Mucor

hiemalis Wehmer,

Monodictys paradoxa

(Corda) Hughes, Mucor

hiemalis Wehmer,

Nigrospora state of

Khuskia oryzae H.J.

Hudson

A. fumigates, $A$. japonicas, A. niger, Fusarium semitectum, Curvularia pallescens, Phoma hedericola, Alternaria tenuissima, $F$, solani, Drechslera australien and A. repens

Aspergillus flavus, Cladosporium sp., Xylaria sp. Adhatoda zeylanica Aspergillus sp., $\quad$ Chaetomium spirale, $\quad$ Curvularia clavata, Penicillium sp. Alternaria alternata, Aspergillus fumigatus, Aspergillus niger, Chaetomium globosum, Cladosporium
B. sublitis, Clavibacter michiganensis, E. coli, $H$. pylori, Micrococcus lysoleikticus, $P$. aeruginosa, Sarcina lutea, Staphylococcus aureus, Streptococcus lactis, fungi (i.e. Alternaria brassicae, Botrytis cinerea, $C$. albicans, Colletotirchum gloeosporioides,

F.graminearum, Phytophthora capsici and Valsa mali

Staphylococcus aureus, B. subtilis, E.coli, Pseudomonas, Aeruginosa, C. albicans and Cryptococcus neoformans

B. subtilis $S$. aureus, $B$. Cereus, E. coli, Klebsilla pneumoniae and $S$. typhimurium

B,subtilis, Enterococcous sp., $K$, pneumoniae, $E$, coli, $S$. typhimurium and $S$. aureus.

Bacillus cereus, Bacillus subtilis , Escherichia coli, Klebsiella pneumoniae, Proteus sp, Pseudomonas sp, ,Salmonella typhi, Staphylococcus aureus, Streptococcus pyogens
[ $\left.{ }^{117}\right]$

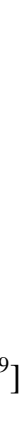




\begin{tabular}{|c|c|c|c|}
\hline Baccharis trimera & 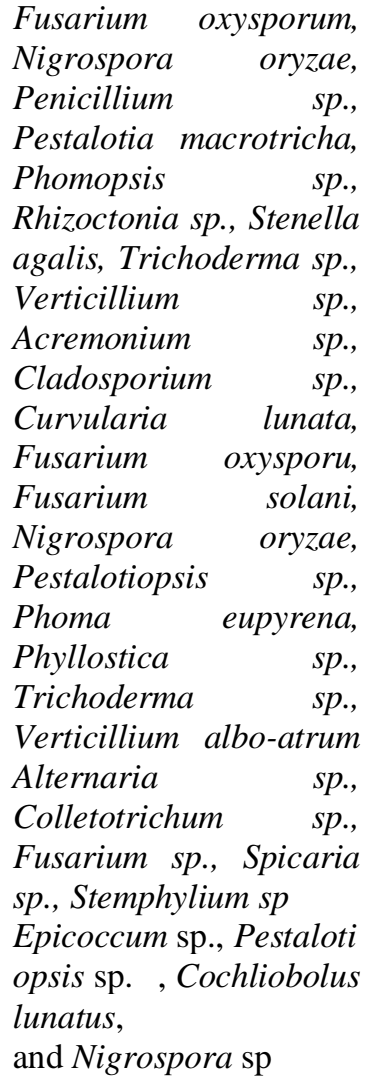 & Not specified & {$\left[{ }^{122}\right]$} \\
\hline
\end{tabular}

\section{Antifungal activity}

Little-studied groups of fungi are considered to be potential sources of novel natural products for medicine and agriculture $\left[{ }^{123}\right]$. The function of invasive fungal infections has increased significantly during cancer organ transplantation, chemotherapy and bone marrow transplantation. Endophytes are presumably ubiquitous in plants, with populations dependent on host species and location. During long research only a few numbers of antifungal agents are available for the treatment of various life threatening fungal infections. The search for new antifungal agents to overcome the growing human problems of drugs resistance in microorganisms is growing. Ongoing global efforts to discover new compounds from $\mathrm{EF}$ of medicinal plants are yielding valuable results $\left[{ }^{124}\right]$. Compounds produced by EF are being recognized as a versatile arsenal of antifungal agents. Many EF have been reported to have fungicidal activity are listed (Table.3).

Table - $\mathbf{3}$ list of endophytic fungal activity against fungi

\begin{tabular}{|c|c|c|c|}
\hline Endophyte & Host plant & Target fungi & Ref \\
\hline Hormonema sp. & $\begin{array}{l}\text { Juniperus } \\
\text { communis }\end{array}$ & $\begin{array}{l}\text { Aspergillus fumigates and } \\
\text { Candida sps }\end{array}$ & {$\left[{ }^{125}\right]$} \\
\hline Alternaria sp. & & $\begin{array}{l}\text { Paracoccidioides brasiliensi } \\
\text { and Schizosaccharomyces } \\
\text { pombe }\end{array}$ & {$\left[{ }^{126}\right]$} \\
\hline $\begin{array}{l}\text { Phaeosphaeria } \\
\text { nodorum }\end{array}$ & $\begin{array}{l}\text { Prunus } \\
\text { domestica }\end{array}$ & $\begin{array}{l}\text { Monilinia fructicola, } \\
\text { Colletotrichum } \\
\text { gloeosporioides }\end{array}$ & {$\left[{ }^{127}\right]$} \\
\hline Chaetomium globosum & Ginkgo & Rhizopus stolonifer & {$\left[{ }^{128}\right]$} \\
\hline No.04 & biloba & Coniothyrium diplodiella. & \\
\hline $\begin{array}{l}\text { Colletotrichum } \\
\text { truncatum, Nigrospora }\end{array}$ & $\begin{array}{l}\text { Jatropha } \\
\text { curcas }\end{array}$ & $\begin{array}{l}\text { Fusarium oxysporum, } \\
\text { Sclerotinia sclerotiorum }\end{array}$ & {$\left[{ }^{129}\right]$} \\
\hline
\end{tabular}


Novel resource and potential of endophytic fungi

oryzae, Fusarium

proliferatum,

Guignardia

cammillae, Alternaria

destruens, and

Chaetomium sp

Pestalotiopsis

mangiferae

Trichoderma

brevicompactum

Mangifera

indica

Allium

sativum

Colletotrichum

gloeosporioides

Botryosphaeria

dothidea

Chaetomium,

Zopfiella, Fusarium,

Purpureocillium,

Arthrinium,

Nigrospora, Eurotium,

Aspergillus,

Penicillium,

Neosartorya,

Talaromyces,

Alternaria,

Curvularia,

Leptosphaerulina,

Bipolaris, Periconia

Phomopsis quercella

Alternaria alternate, Aspergillus flavus, A.terreus , A.niger

Not specified

\section{Curvularia lunata}

Xylaria sp. strain PB3f3

Alternaria solani

Alternaria, Aureobasidium,
Michelia

champaca

Melia

azedarach

Tephrosia

purpurea

Cephalotax

us

hainanensi

Suaeda

maritima,

Suaeda

monoica.

Ocimum

sanctum,

Cymbopog

on caesius

Haematoxy

lon

brasiletto

Heptacodiu

$m$

miconioide

$s$

Cactus

Opuntia
Aloe vera
Candida albicans

Fusarium

oxysporum, Colletotrichum

lindemuthianum, $C$.

ampelinum, Rhizoctonia

solani, Botrytis cinerea

Cladosporium

cladosporioides,

C.

sphaerospermum

Alternaria solani

$\left[{ }^{130}\right]$

$\left[{ }^{66}\right]$

$\left[{ }^{131}\right]$

$\left[{ }^{132}\right]$

Sclerotinia sclerotiorum, Phytophthora parasitica var. nicotianae, Phytophthora melonis, Botrytis cinerea, Colletotrichum gloeosporioides, Rhizoctonia solani

Rhizoctonia solani, Fusarium oxysporum

Rhizoctonia solani, Fusarium oxysporum, Colletotrichum falcatum and Helminthosporium maydis.

Candida albicans, Trichophyton rubrum

Alternaria solani, Fusarium oxysporum

Rhizoctorzia solani, Valsa mali

Opuntia humifusa

$\left[{ }^{140}\right]$ 


\begin{tabular}{l}
\hline Cladosporium, \\
Cryptococcus, \\
Curvularia, Diaporthe, \\
Epicoccum, \\
Paraconiothyrium, \\
Pestalotiopsis and \\
Phoma
\end{tabular}

\section{Antiviral compounds}

The discovery of the potential antiviral compounds from EF is still in its infancy. There is only limited number of compounds reported as antiviral agents from fungal endophytes. The main limitation to antiviral compound discovery is most probably related to the absence of antiviral screening systems. Altertoxins was isolated $\left[{ }^{141}\right]$ from Alternaria tenuissima QUE1Se have HIV-1 virus activity. Several hundred endophytic fungal extracts were evaluated on HIV-1 replication in T-lymphocytes, and out of that four extracts are non-toxic and exhibited inhibitory with the range of $75 \%$ to $99 \%$ and out of three of these extracts were fractionated and fraction DB-2 completely inhibited HIV-1 replication at concentration that was also found it is not cytotoxic $\left[{ }^{142}\right]$. In antiviral activity was reported against influenza A viral $\left.\left(\mathrm{H}_{1} \mathrm{~N}_{1}\right){ }^{143}\right]$ for the compounds emerimidine (A, B) ,emeriphenolicins (A,D), aspernidine (A , B) austin, austinol, dehydroaustin, and acetoxy dehydroaustin for Emericella sp.(HK-ZJ) which is isolated from of plant Aegiceras corniculatum. A source of several natural products has been in the endophytic fungi that live within desert plants. $\left.{ }^{144}\right]$ purified coumarins from Alternaria Species in Calophyllum inophyllum. Endophytes Aspergillus, Curvularia, Fusicoccum, Guignardia, Muscodor, Penicillium, Pestalotiopsis, and Phomopsis spp isolated $\left[{ }^{145}\right]$ from Garcinia plants and evaluated against Herpes simplex virus type 1 (HSV-1 ATCC VR260 ) and most of fungi exhibited weak to moderate antiviral activity against. EF isolated $\left.{ }^{146}\right]$ from 81 thai medicinal plant species out of 582 pure isolates obtained 40 species have strong anti-viral activity against HSV-1.

\section{Anticancer substances}

Cancer is a group of diseases that can affect various organs of the body, and is characterized by the uncontrolled growth of abnormal cells and lead to death. It is a major cause of death worldwide. So far chemical inhibitors of carcinogenesis are mostly kinase inhibitors in the form of small molecules, antibodies and organic chemicals. The research and development of anticancer drugs is expensive which places a high financial burden on individual healthcare costs and government budgets. Medicinal plants are being reduced significantly due to over-harvesting, illegal exploitation and destruction of ecological habitat $\left[{ }^{147}\right]$ to conserve endangered medicinal plants and need to develop new alternative resources for harvesting anticancer compounds from plants. Anti-cancer drugs of natural products from EF are of are cheap and great value. The EF has been recognized as a possible useful source of bioactive secondary metabolites, especially in anticancer application $\left[{ }^{148}\right]$. More than $60 \%$ of the anticancer and $70 \%$ of the antimicrobial drugs and compounds are currently in clinical use are natural products or natural product derivatives. There is an increase in need for a universal natural bioactive compound that can be used to suppress carcinogenic growth potential $\left[{ }^{149}\right]$. Likewise, there are large numbers of anticancer agents produced by fungal endophytes inhabiting different medicinal plants. For the sake of convenience, some of the endophytic fungi showed anticancer activity against cell lines are presented in the form of a table (Table.4). 
Novel resource and potential of endophytic fungi

Table- 4 list of endophytic fungi against Cell lines

\begin{tabular}{|c|c|c|}
\hline Plant and Endophytic fungi & Targeted Cell lines & Ref \\
\hline Xylopia aromatic/Periconia atropurpurea & HeLa and $\mathrm{CHO}$ & {$\left[{ }^{150}\right]$} \\
\hline Cynodon dactylon/Aspergillus fumigates & K562 & {$\left[{ }^{151}\right]$} \\
\hline Terminalia arjuna/Pestalotiopsis terminaliae & $\begin{array}{l}\text { BT220, H116, Int 407, HL } 251 \text { and } \\
\text { HLK } 210\end{array}$ & [52] \\
\hline citrifolia Linn/Botryodiplodia & Breast cancer & {$\left[{ }^{153}\right]$} \\
\hline Aquilaria sinensis (3087095) & $\begin{array}{l}\text { human -HepG2, MCF7, SKVO3, HL- } \\
60 \text {, and 293-T }\end{array}$ & {$\left[{ }^{154}\right]$} \\
\hline Cephalotheca faveolata & Colon cancer HCT-116 & {$\left[{ }^{155}\right]$} \\
\hline Undaria pinnatifida/Guignardia sp & $\mathrm{KB}$ & {$\left[{ }^{156}\right]$} \\
\hline Sonneratia caseolaris/ Bionectria ochroleuca & L5178Y & {$\left[{ }^{157}\right]$} \\
\hline $\begin{array}{l}\text { Barringtonia } \\
\text { gloeosporioides }\end{array}$ & HT29 & {$\left[{ }^{158}\right]$} \\
\hline Astragalus lentiginosus /Emericella sp. AST003 & SF-268 and MDA-MB-231 & {$\left[{ }^{159}\right]$} \\
\hline Ocimum tenuiflorum/Penicillium citrinum & L5178Y & {$\left[{ }^{160}\right]$} \\
\hline Taxus chinensis/Perenniporia tephropora & HeLa, SMMC-7721 and PANC-1 & {$\left[{ }^{85}\right]$} \\
\hline Dysoxylum binectariferum/Fusarium proliferatum & HCT-116 and MCF-7 & {$\left[{ }^{161}\right]$} \\
\hline Cinпатотит mollissimum & P388 & [62] \\
\hline Artemisia lactiflora & HL-60, MCF-7 and COLO205 & {$\left[{ }^{163}\right]$} \\
\hline Ajuga decumbens/Myrothecium roridum & HepG2 & {$\left[{ }^{164}\right]$} \\
\hline Bacopa monnieri & HCT-116, MCF-7, PC-3 and A-549 & {$\left[{ }^{165}\right]$} \\
\hline Pongamia pinnata/Phomopsis glabrae & Not specified & {$\left[{ }^{166}\right]$} \\
\hline Phyllanthus amarus/Trichothecium sp & HeLa and B16F10 & {$\left[{ }^{61}\right]$} \\
\hline Morinda citrifolia Linn. & $\begin{array}{l}\text { LU-1 (lung), PC-3 (prostate), and } \\
\text { MCF-7 (breast) }\end{array}$ & {$\left[{ }^{167}\right]$} \\
\hline Catharanthus roseus/Talaromyces radicus & HeLa cells & {$\left[{ }^{168}\right]$} \\
\hline Pogostemon cablin/Bipolaris sorokiniana A606 & $\begin{array}{l}\text { MCF-7, NCI-H460, SF-268 and HepG- } \\
2\end{array}$ & {$\left[{ }^{139}\right]$} \\
\hline
\end{tabular}

\section{Immune suppressive drugs}

Large number of novel immunomodulatory compounds has been isolated from endophytic fungi. Since long years intensive search is going for the identification of effective agents to deal with immunological disorders related to mainly graft rejection and various other autoimmune diseases. The modulation of immune response with the aid of various bioactives in order to alleviate certain diseases is an active area of interest. There is a huge potential for production of these drugs from the alternative source and one of them could be endophytes. Microbial endophytes mimic the bioactive compounds as produced by the plant itself thus making them a promising source of novel compounds. Entrophospora infrequens isolated from Nothapodytes foetida (Wight) Sleumer and their chloroform (CEEI) and methanolic extracts showed delayed type hypersensitivity (DTH) reaction $\left[{ }^{169}\right]$, and further screened for plaque forming cell phagocytic response and haemagglutination antibody titre (IgM and $\mathrm{IgG}$ ). Three were compounds isolated from Pestalotiopsis leucothës from plant Tripterygium wilfordii, and evaluated and found variable effects on T- and B-cells and monocytes [170]. Out of several isolates and their extracts of Pestalotiopsis leucothës, Mucor sp. Verticillium sp. and Pestalotiopsis disseminate from Tripterygium wilfordii Hook stimulated proliferation of human peripheral blood mononuclear cells (PBMC) was reported by $\left[{ }^{171}\right] .\left[{ }^{172}\right]$ Isolated fractions from root fungal endophytic of Tulsi (Ocimum sanctum Linn.) and screened for In vitro immunomodulatory activities on the functions of human polymorphonuclear (PMN) cells such as phagocytosis. 
Tripterygium wilfordii, produces subglutinol A and diterpene pyrones with showed immunosuppressive activity $\left[{ }^{173}\right]$. Taxol (paclitexel) is an important anticancer drug used widely in the clinical field isolated from EF of Pestalotiopsis microspora, bark of Himalayan yew Taxus brevifolia $\left[{ }^{174,175}\right]$. .

\section{Antidiabetic activity}

The nature has provided abundant natural resources which can be explored for their medicinal uses. Diabetes, often referred to by doctors as diabetes mellitus, describes a group of metabolic diseases in which the person has high blood glucose (blood sugar), either because insulin production is inadequate, or because the body's cells do not respond properly to insulin, or both [176]. Nowadays diabetes is growing as important serious public health problem, particularly in developed countries as a major threat to global development. We need to find natural and effective antidiabetic drugs. Several researchers are investigated antidiabetic and hypolipidemic activity of EF [177, 178]. [179] isolated antidiabetic peptide from EF Aspergillus awamori from medicinal plant Acacia nilotica and its purified compound was further identified using HPLC. Lectin ( $\mathrm{N}$-acetylgalactosamine, $64 \mathrm{kDa}$ ) was isolated from EF, Alternaria species from plant Viscum album tested for In vitro and in vivo antidiabetic activity on rats [180].14 endophytic fungi isolated from Taxus sumatrana and tested for alpha-glucosidase inhibitor activity[181].

\section{Antioxidant activities}

Antioxidants have become the topic of interest recently. The field of free radical chemistry is gaining more attention now a days. Free radicals are reactive oxygen and nitrogen species which are generated by various physiological processes in the body. Uncontrolled generation of free radicals leads to attack on membrane lipids, proteins, enzymes and DNA causing oxidative stress and ultimately cell death. These ROS are responsible for many degenerative human diseases like neurodegenerative disorders, cancer, Alzheimer's disease, ageing, Parkinson's disease, diabetes mellitus, atherosclerosis, and inflammatory diseases. Protection against free radicals can be enhanced by taking sufficient amounts of exogenous antioxidants. An antioxidant is a stable molecule which donates an electron to a rampaging free radical and terminates the chain reaction before vital molecules are damaged. Dietary antioxidants, including polyphenolic compounds, vitamin E and $\mathrm{C}$ are believed to be the effective nutrients in the prevention of oxidative stress related diseases. Fungal endophytes represent an abundant and dependable source of novel antioxidant compounds $\left[{ }^{182-184}\right]$. Lot of studies were conducted as antiviral, anticancer, antidiabetic and antimicrobial effects to test the potential effects of fungal endophytes, but very few scientists worked on their antioxidant capacity $\left.\left[{ }^{185,186}\right] .{ }^{187}\right]$ was conducted antioxidant properties using EF Phyllosticta sp. which is isolated from medicinal plant Guazuma tomentosa and also quantified phenol and flavonoid content. Antioxidant was screened $\left[{ }^{188}\right]$ with the 2,2'-azinodi(3-ethylbenzthiazoline-6-sulfonic acid) (ABTS) decolorization assay and 2,2'-diphenyl-1-picrylhydrazyl (DPPH) found this EF have potential novel source of natural antioxidants. Antioxidant was screened for EF in medicinal plants Rhodiola crenulata, $R$. angusta, and $R$. sachalinensis $\left[{ }^{189}\right]$. DPPH, FRAP, and Iron chelating activity are conducted using endophytes Asperigillus niger, Penicillium sp. and Trichoderma $\left.s p .{ }^{190}\right]$. Antioxidant compounds isolated from Acremonium $s p$ identified as sesquiterpene 3,5-dihydroxy-2,5-dimethyltrideca2,9,11-triene- 4,8-dione findings based on spectroscopic data, including $1 \mathrm{H}$ NMR, 13C-NMR, HMQC, HMBC, and COSY $\left[{ }^{191}\right]$.

\section{Antiarthritis and Anti-inflammatory activities}


Historically, the best resources for novel scaffolds have always been natural products. Immune system of our body plays a crucial role, as an overactive immune system may lead to certain fatal disease like arthritis. Rhematoid arthritis(RA) is chronic, inflammatory, and systemic autoimmune disease, symptoms include pain, swelling, and destruction of cartilage and bone as a result of which permanent disabilities occur but the exact etiology is unknown. Nowadays, researcher shows a great interest in those finding medicinal agents that are derived from microbial source because of the currently available drugs are either have certain side effects or are highly expensive $\left[{ }^{192}\right]$. Endophytic fungi Talaromyces wortmannii isolated from medicinal plant Aloe vera and further seperated as several pure substances and out of that component $\mathrm{C}$ showed potent anti-inflammatory activity and this ability was gained for this metabolite is due to inhibition of IL-8 release by blocking NF- $\mathrm{BB}$ and AP-1 activation $\left[{ }^{193}\right]$. Compound Mutolide was isolated from the coprophilous fungus Lepidosphaeria sp. (PM0651419) and showed good anti-inflammatory activity and in future it can be used as druggable candidate for the treatment of inflammatory diseases like RA $\left[{ }^{194}\right]$. The primary purpose for such broad-based screening of endophytic fungi was to identify novel inhibitors of proinflammatory cytokines involved in various immunological pathways. Ergoflavin a pigment isolated from EF which is growing on the leaves of an Indian medicinal plant Mimosops elengi (bakul) showed good anti-inflammatory activity $\left[{ }^{195}\right]$. Endophytes alternative to chemical comounds which are shown excellent anti-inflammatory and various biological activities (Figure. 4).

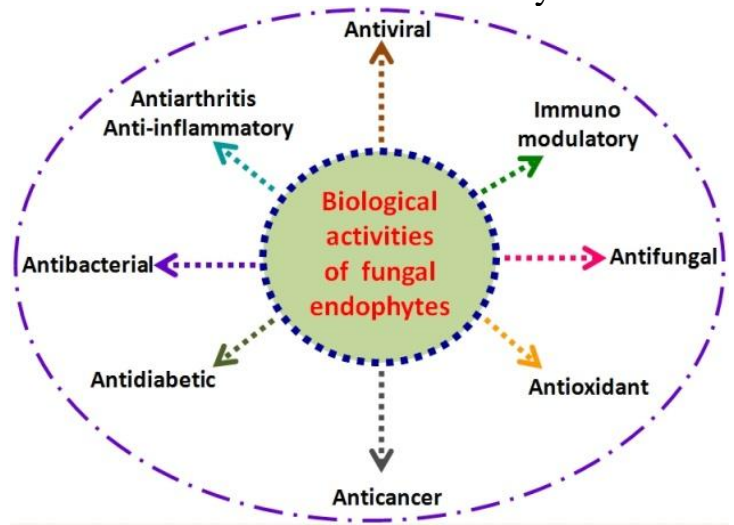

Figure. 4 Biological activities of fungal endophytes

\section{CONCLUSION}

Endophytic fungi can produce same or similar compounds originated from their host plants. Endophytic microorganisms are a huge reservoir of genetic diversity. Insights gained into endophyte-endophyte and plant-endophyte communication can be beneficial to biomedical community and the endophyte synthesized and secreted chemicals can be of importance to the society for the development of novel antibiotics against deadly pathogens. However, only a few numbers of antifungal agents are now available for the treatment of various life threatening fungal infections. There is an ongoing need for novel drugs that are highly effective in the treatment of cancer, drug resistant bacteria, and fungal infections. However, the application of microorganisms by the pharmaceutical and food industries to obtain different compounds of interest is still modest. Antioxidants have become the topic of interest recently. Fungal endophytes represent an abundant and dependable source of novel antioxidant compounds. There has been 
increasing interest in systematics, evolutionary biology, ecology and applied research of endophytic fungi. A number of previous studies have demonstrated that ITS based is insufficient for some species delimitation, especially in rapidly evolving or highly diverse genera so we need more advanced techniques to solve these kinds of challenges. During the developments of modern biotechnology and taking advantage of genetic engineering, metabolic technology and their better use to manipulate this important microbial resource, and to make benefit of mankind.

\section{ACKNOWLEDGMENTS}

VVR would like to thank to Ministry of Earth Sciences, New Delhi, India (MoES / 36 / OOIS / Extra / 18 /2013) for financial support.

\section{REFERENCES}

1. Sunitha V, Nirmala D, Srinivas C. Extracellular enzymatic activity of endophytic fungal strains isolated from medicinal plants. World Journal of Agricultural Sciences. 2013; 9(1):01-09.

2. Krings M, Taylor TN, Hass H, Kerp H, Dotzler N, Hermsen EJ. Fungal endophytes in a 400-million-yr-old land plant: infection pathways, spatial distribution, and host responses. New Phytol. 2007; 174: 648-657.

3. Arnold AE. Diversity and ecology of fungal endophytes in tropical forests. In Current Trends in Mycological Research, D. Deshmukh, ed. (New Delhi, India: Oxford \& IBH Publishing Co. Pvt. Ltd.), 2005:pp. 49-68.

4. Kumaresan V, Suryanarayanan TS. Endophytes assemblages in young mature and senescent leaves of Rhizophora apiculata: evidence for the role of endophytes in mangrove litter degradation. Fungal Diversity. 2002;9: 81-91.

5. Carroll G. Fungal endophytes in stems and leaves from latent pathogen to mutualistic symbiont. Ecology. 1988; 69 (1): 2-9.

6. Petrini O. Fungal endophytes of tree leaves. In: Andrews JH, Hirano SS, eds. Microbial Ecology of Leaves. New York: Spring Verlag. 1991;179-197.

7. Dreyfuss MM, Chapela IH. Potential of fungi in discovery of novel low molecular weight pharmaceuticals. In: The discovery of Natural Products with Therapeutic Potential (ed. V.P. Gullo). Butterworth-Heinemann, London, UK: 1994; 49-80.

8. Schulz B, Rommert AK, Dammann U, Aust HJ, Strack D. The endophyte-host interaction: a balanced antagonism. Mycol. Re. 1999;103:1275-1283.

9. Strobel GA, Daisy B. Bioprospecting for microbial endophyes and their natural products. Microbiology and Molecular Biology Reviews. 2003; 67: 491-502.

10. Tomita F. Endophytes in Southeast Asia and Japan: their taxonomic diversity and potential applications. Fungal Diversity. 2003; 14: 187-204.

11. Urairuj C, Khanongnuch, C, Lumyong S. Ligninolytic enzymes from tropical endophytic Xylariaceae. Fungal Diversity. 2003;13: 209-219.

12. Wildman HG. The rise and fall of natural products screening for drug discovery. Fungal Diversity. 2003; 13: 221-231.

13. Melotto M, Underwood W, He SY. Role of stomata in plant innate immunity and foliar bacterial diseases. Annu Rev Phytopathol. 2008; 46:101-122.

14. Hoffman MT, Arnold AE. Geographic locality and host identity shape fungal endophyte communities in cupressaceous trees. Mycological Research. 2008; 112: 331e344.

15. Firáková S, Sturdíková M, Múcková M. Bioactivity secondary metabolites produced by microorganisms associated with plants. Biol. Bratislava- Section Botany. 2007; 62: 251257.

16. Sridhar K, Raviraja N. Endophytes. A crucial issue. Current Science1995;69: 570-571.

17. Hawksworth DC,Rossman AY. Where are the undescribed fungi? Phytopathology. 1987; 87: 888-891.

18. Schulz B, Boyle C. The endophytic continuum. Mycol. Res. 2005; 109: 661-686. 
Novel resource and potential of endophytic fungi

19. Arnold AE. Understanding the diversity of foliar endophytic fungi: progress, challenges, and frontiers. Fungal Biol. Rev. 2007; 21: 51-66.

20. Arnold AE. Endophytic fungi: hidden components of tropical community ecology. In Tropical Forest Community Ecology, W.P. Carson and S.A. Schnitzer, eds. (West Sussex, UK: Wiley-Blackwell), 2008. pp. 254-271.

21. Stone J, White J, Polishook J. Endophytic Fungi. In Mueller; et al.Measuring and Monitoring Biodiversity of Fungi. Inventory and monitoring methods. Elsevier Academic Press, Boston MA, 2004; pp. 241-270.

22. Sinclair JB, Cerkauskas RF. Latent infection vs. endophytic colonization by fungi. In: Redlin SC, Carris LM, editors. Endophytic fungi in grasses and woody plants: systematics, ecology, and evolution. St. Paul (MN): APS Press.1996. p. 3-29.

23. Zheng RY, Jiang H. Rhizomucor endophyticus sp. nov., an endophytic zygomycetes from higher plants. Mycotaxon. 1995; 56: 455-466.

24. White JF. Endophyte-host associations in forage grasses . A proposal concerning origin and evolution. Mycologia. 1988; 80 (4): 442-446.

25. Clay K, Schardl C. Evolutionary origins and ecological consequences of endophyte symbiosis with grasses. Am Nat. 2002;160:99-127.

26. Saikkonen K, Faeth SH, Helander M, Sullivan TJ. Fungal endophytes: A Continuum of Interactions with Host Plants.Annu. Rev. Ecol. Syst.1998; 29:319-343.

27. Faeth SH. Are endophytic fungi defensive plant mutualists? Oikos. 2002; 98 (1): 25-36

28. Faeth SH, Gardner DR, Hayes CJ, Jani A, Wittlinger SK, Jones TA. Temporal and spatial variation in alkaloid levels in Achnatherum robustum, a native grass infected with the endophyte Neotyphodium. Journal of Chemical Ecology. 2006; 32 (2): 307-324.

29. Faeth SH, Sullivan TJ. Mutualistic asexual endophytes in a native grass are usually parasitic. American Naturalist. 2003;161 (2): 310-325.

30. Lodge DJ, Fisher PJ, Sutton BC. Endophytic fungi of Manilkara bidentata leaves in Puerto Rico. Mycologia.1996;88: 733-738.

31. Zhang Y, Mu J, Feng Y et al . Broad-spectrum antimicrobial epiphytic and endophytic fungi from marine organisms: isolation, bioassay and taxonomy. Mar Drugs. 2009; 7:97112.

32. Sette LD, Passarini MRZ, Delarmelina C, Salati F, Duart MCT. Molecular characterization and antimicrobial activity of endophytic fungi from coffee plants. World Journal of Microbiology and Biotechnology. 2006; 22: 1185-1195.

33. Beever RE, Weeds PL. Taxonomy and Genetic Variation of Botrytis and Botryotinia. In: Elad Y, Williamson B, Tudzynski P, Delan N. Eds. Botrytis: Biology, Pathology and Control, Kluwer Academic Publishers, Dordrecht, 2004; 29-52.

34. Xiang Sun, Liang-Dong Guo. Endophytic fungal diversity: review of traditional and molecular techniques. Mycology. 2012; 3 (1): 65-76.

35. Naupaka B. Zimmerman, Peter M. Vitousek. Fungal endophyte communities reflect environmental structuring across a Hawaiian landscape. Proc Natl Acad Sci. 2012; 109(32): 13022-13027.

36. Margulies M, Egholm M, Altman WE, Attiya S, Bader JS,Bemben LA, Berka J, Braverman MS, Chen YJ, Chen ZT, et al. Genome sequencing in microfabricated highdensitypicolitre reactors. Nature. 2005; 437: 376-380.

37. Jumpponen A, Jones KL. Massively parallel 454 sequencingindicates hyperdiverse fungal communities in temperate Quercus macrocarpa phyllosphere. New Phytol. 2009; 18:438444.

38. Gharizadeh B, Norberg E, Löffler J, Jalal S, Tollemar J,Einsele H, Klingspor L, Nyrén P. Identification of medically important fungi by the Pyrosequencing (TM) technology. Mycoses. 2004;47: 29-33.

39. Monchy S, Sanciu G, Jobard M, Rasconi S, Gerphagnon M,Chabé M, Cian A, Meloni D, Niquil N, Christaki U, et al. Exploring and quantifying fungal diversity in freshwaterlake ecosystems using rDNA cloning/sequencing and SSU tag pyrosequencing. Environ Microbiol. 2011;13: 1433-1453.

40. Ovaskainen O, Nokso-Koivista J, Hottola J, Rajala T, PennanenT, Ali-Kovero H, Miettinen O, Oinonen P, Auvinen P,Paulin L, et al. Identifying wood-inhabiting fungi 
with 454 sequencing - what is the probability that BLAST gives the correct species? Fungal Ecol. 2010; 3: 274-283.

41. Jumpponen A, Jones KL, Blair J. Vertical distribution of fungal communities in tallgrass prairie soil. Mycologia. 2010; 102:1027-1041.

42. Dumbrell AJ, Ashton PD, Aziz N, Feng G, Nelson M,Dytham C, Fitter AH, Helgason T. Distinct seasonalassemblages of arbuscular mycorrhizal fungi revealedby massively parallel pyrosequencing. New Phytol. 2011;190:794-804.

43. Hebert PDN, Cywinska A, Ball SL, de Waard JR. Biological identifications through DNA barcodes. Proc R Soc (Lond) B. 2003; 270: 313-321.

44. Vilgalys R. Taxonomic misidentification in public DNA database. New Phytol. 2003;160: 4-5.

45. Nilsson RH, Ryberg M, Abarenkov K, Sjökvist E, Kristiansson E. The ITS region as a target for characterization of fungal communities using emerging seq technologies. FEMS Microbiol Lett. 2009; 296(1):97-101.

46. Gazis R, Rehner S, Chaverri P. Species delimitation in fungal endophyte diversity studies and its implications in ecological and biogeographic inferences. Mol Ecol. 2011; 20:3001-3013.

47. Duon gLM, Jeewon R, Lumyong S, Hyde KD. DGGE coupled with ribosomal DNA gene phylogenies reveal uncharacterized fungal phylotypes. Fungal Diversity. 2006; 23: 121 138.

48. Tao G, Liu, ZY, Hyde KD, Lui XZ, Yu ZN. Whole rDNA analysis reveals novel and endophytic fungi in Bletilla ochracea (Orchidaceae). Fungal Diversity. 2008;33:101-122.

49. David Ezra, Hess WM, Gary A. Strobel. New endophytic isolates of Muscodor albus, a volatile-antibiotic-producing fungus. Microbiology. 2004;150: 4023-4031.

50. Ida Chapaval Pimentel, Chirlei Glienke-Blanco, Juarez Gabardo, Rodrigo Makowiecky Stuart, João Lúcio Azevedo. Identification and colonization of endophytic fungi from soybean (Glycine max (L.) Merril) under different environmental conditions. Braz. arch. biol. Technol. 2006; 49:5.

51. HuangWY, CaiYZ, Surveswaran S, Hyde KD, Corke H, Sun M. Molecular phylogenetic identification of endophytic fungi isolated from three Artemisia species. Fungal Diversity. 2009; 36: 69-88.

52. Pramuan Saithong, Wanchai Panthavee, Siriporn Stonsaovapak, Li Congfa. Isolation and primary identification of endophytic fungi from Cephalotaxus mannii trees. Maejo Int. J. Sci. Technol. 2010; 4(3):446-453

53. Tayung K, BarikBP, Jha DK, Deka DC. Identification and characterization of antimicrobial metabolite from an endophytic fungus, Fusarium solani isolated from bark of Himalayan yew. Mycosphere. 2011; 2(3):203-213.

54. Mohammad Hossein Mirjalili, Mohsen Farzaneh, Mercedes Bonfill, Hassan Rezadoost, Alireza Ghassempour. Isolation and characterization of Stemphylium sedicola SBU-16 as a new endophytic taxol-producing fungus from Taxus baccata grown in Iran. FEMS Microbiol Lett. 2012 328:122-129

55. Prasetyawan Yunianto, Syofi rosmalawati, Indra rachmawati, Wahyudi priyono suwarso, Wahono sumaryono. Isolation and Identification of Endophytic Fungi from Srikaya Plants (Annona squamosa) having potential secondary metabolites as anti-breast aancer activity. Microbiology Indonesia. 2012; 6 (1): 23.

56. Roland M. Hipol. Molecular Identification and Phylogenetic Affinity of Two Growth Promoting Fungal Endophytes of Sweet Potato (Ipomea batatas (L.) Lam.) from Baguio City, Philippines. Electronic Journal of Biology. 2012;8(3): 57-61.

57. Abdul Latif Khan,Muhammad Hamayun,Javid Hussain,Sang-Mo Kang, In-Jung Lee. The Newly Isolated endophytic fungus Paraconiothyrium sp. LK1 Produces Ascotoxin. Molecules. 2012; 17: 1103-1112.

58. Rhoden SA, Garcia A, Rubin Filho CJ, Azevedo JL, Pamphile JA.Phylogenetic diversity of endophytic leaf fungus isolates from the medicinal tree Trichilia elegans (Meliaceae).Genet. Mol. Res. 2012; 11 (3): 2513-2522.

59. Premalatha K, Kalra A. Molecular phylogenetic identification of endophytic fungi isolated from resinous and healthy wood of Aquilaria malaccensis, a red listed and highly exploited medicinal tree. Fungal Ecology. 2013; 6(3): 205-211. 
Novel resource and potential of endophytic fungi

60. Temesgen Belayneh Mulaw, Irina S. Druzhinina, Christian P. Kubicek, Lea Atanasova. Novel Endophytic Trichoderma spp. Isolated from Healthy Coffea arabica roots are capable of controlling coffee Tracheomycosis. Diversity. 2013; 5:750-766.

61. Ravindra Taware,Prasad Abnave,Deepak Patil,Pattuparambil Ramanpillai Rajamohanana n,Remya Raja,Gowrishankar Soundararajan,Gopal Chandra Kundu, Absar Ahmad. Isolation, purification and characterization of Trichothecinol-A produced by endophytic fungus Trichothecium sp. and its antifungal, anticancer and anti-metastatic activities. Sustainable Chemical Processes. 2014; 2:8.

62. Kathamuthu Gokul Raj, Natesan Sundaresan, Enthai Jagan Ganeshan, Pandi Rajapriya, Johnpaul Muthumary, Jayavel Sridhar, and Mohan Pandi. Phylogenetic reconstruction of endophytic fungal isolates using internal transcribed spacer 2 (ITS2) region. Bioinformation. 2014; 10(6): 320-328.

63. Narayan Chandra Paul,Hyang Burm Lee,Ji Hye Lee,Kyu Seop Shin, Tae Hee Ryu, Hye Ri Kwon , Yeong Kuk Kim, Young Nam Youn, Seung Hun Y. Endophytic Fungi from Lycium chinense Mill and Characterization of Two New Korean Records of Colletotrichum. Int. J. Mol. Sci. 2014; 15:15272-15286.

64. Chandramouli Manasa, Monnanda Somaiah Nalini. L-Asparaginase Activity of Fungal Endophytes from Tabernaemontana heyneana Wall. (Apocynaceae), Endemic to the Western Ghats (India), International Scholarly Research Notices Volume 2014(2014); Article ID 925131, 7 pages,http://dx.doi.org/10.1155/2014/925131.

65. Yixin Qian, Jichuan Kang, Kun Geng, Lu Wang,Bangxing Lei. Endophytic Fungi from Artemisia argyi Levl. et Vant. and Their Bioactivity. Chiang Mai J. Sci. 2014; 41(4): 910 921.

66. Li ZF, Wang LF, Feng ZL, Zhao LH, Shi YQ, Zhu HQ. Diversity of endophytic fungi from different Verticillium-wilt-resistant Gossypium hirsutum and evaluation of antifungal activity against Verticillium dahliae In vitro. J Microbiol Biotechnoly. 2014: 24(9):1149-61.

67. Xuping Shentu, Xiaohuan Zhan, Zheng Ma, Xiaoping Yu,and Chuanxi Zhang. Antifungal activity of metabolites of the endophytic fungus Trichoderma brevicompactum from garlic. Braz J Microbiol. 2014; 45(1):248-254.

68. Roland M. Hipol, Liezel M. Magtoto, Sigrid Minette A. Tamang, Amor M. Damata. Antioxidant Activities of Fungal Endophytes Isolated from Strawberry Fragaria $\mathrm{x}$ ananassa Fruit. Electronic Journal of Biology. 2014; 10(4):107-112

69. Karen V. Ambrose, Zipeng Tian, Yifei Wang, Jordan Smith,Gerben ZylstraBingru Huang Faith C. Belanger. Functional characterization of salicylate hydroxylase from the fungal endophyte Epichloë festucae. Scientific Reports. 2015; 5: Article number: 10939.

70. Xiuna Wang,Xiaoling Zhang,Ling Liu,Meichun Xiang,Wenzhao Wang,Xiang Sun, Yongs hene,Liangdong Guo,Gang Liu,Liyun Guo,Chengshu Wang,WenBing Yin,Marc Stadler, Xinyu Zhang,Xingzhong Liu. Genomic and transcriptomic analysis of the endophytic fungus Pestalotiopsis fici reveals its lifestyle and high potential for synthesis of natural products. BMC Genomics. 2015; 16:28

71. Chowdhary K, Kaushik N. Fungal Endophyte Diversity and Bioactivity in the Indian Medicinal Plant Ocimum sanctum Linn. PLoS One. 2015;10(11): e0141444.

72. Roland M. Hipol, Sigrid Minette A. Tamang, Buena Florl Gargabite, Regina Lourdes C. Broñola-Hipol. Diversity of fungal endophytes isolated from Marchantia polymorpha populations from Baguio City, Philippines. Bull. Env.Pharmacol. Life Sci. 2015; 4(3): 8791

73. Latiffah Zakaria, Muhamad Izham Muhamad Jamil, Intan Sakinah Mohd Anuar. Molecular characterisation of endophytic fungi from roots of wild banana (Musa acuminata). Trop Life Sci. Res 2016;27(1): 153-162.

74. Rukaia Gashgari, Youssuf Gherbawy, Fuad Ameen, Salam Alsharari. Molecular Characterization and Analysis of Antimicrobial Activity of Endophytic Fungi From Medicinal Plants in Saudi Arabia. Jundishapur J Microbiol. 2016; 9(1): e26157.

75. Cosoveanu A, Cabrera R, Hernandez M, Iacomi-Vasilescu B, Zhang X, Shu S, Wang M. Fungi as endophytes in Chinese Artemisia spp juxtaposed elements of phylogeny, diversity and bioactivity. Mycosphere.2016; 7(2):102-117. 
76. Xincong Kang, Chichuan Liu, Dongbo Liu, Lu Zeng, Qianqian Shi, Kun Qian, Bingyan Xie. The complete mitochondrial genome of huperzine A-producing endophytic fungus Penicillium polonicum. Mitochondrial DNA Part B. 2016;1(1): 202-203.

77. Savitha J, Bhargavi SD, Praveen VK. Complete genome sequence of the endophytic fungus Diaporthe ampelina(Phomopsis). Genome Announcement. 2016;4(3):e00477-16

78. Goutam J. Isolation and identification of antibacterial compounds isolated from endophytic Fungus Emericella qaudrilineata. Nat Prod Chem Res. 2016; 4:205. doi:10.4172/2329-6836.1000205.

79. Ranga K. Dissanayake, Pamoda B. Ratnaweera, David E.Williams C. Dilrukshi Wijayarathne, Ravi L. C. Wijesundera Raymond Andersen J, Dilip de Silva E. Antimicrobial activities of endophytic fungi of the Sri Lankan aquatic plant Nymphaea nouchali and chaetoglobosin $\mathrm{A}$ and $\mathrm{C}$, produced by the endophytic fungus Chaetomium globosum. Mycology. 2016; 7(1): 1-8.

80. Abirami G, Boominathan M. Antioxidant Activity of Endophytic Fungi Isolated from Hugonia mystax L. Journal of Academia and Industrial Research. 2016; 5(1):10-13.

81. Min Qiu, Rui-sheng Xie,Yu Shi, Haihua Zhang, Hai-min Chen. Isolation and identification of two flavonoid-producing endophytic fungi from Ginkgo biloba L. Ann Microbiol. 2010; 60:143-150.

82. Yi Hsiao, Hsun-Shuo Chang, Ta-Wei Liu , Sung-Yuan Hsieh , Gwo-Fang Yuan , MingJen Cheng, Ih-Sheng Chen. Secondary Metabolites and Bioactivity of the Endophytic Fungus Phomopsis theicola from Taiwanese endemic plant. Rec. Nat. Prod. 2016;10(2). 189-194.

83. Huiru Zhang, Xinchen Sun, Chunping Xu. Antimicrobial activity of endophytic fungus fusarium sp. isolated from medicinal honeysuckle plant. Arch. Biol. Sci. Belgrade. 2016; 68(1): 25-30.

84. El-Hawary SS, Mohammed R,. AbouZid SF, Bakeer W, Ebel R, Sayed M, Rateb. ME. Solamargine production by a fungal endophyte of Solanum nigrum. Journal of applied Microbiology.2016;120(4): 900-911.

85. Ling-Shang Wu, Min Jia, Ling Chen , Bo Zhu , Hong-Xiu Dong, Jin-Ping Si, Wei Peng, Ting Han. Cytotoxic and Antifungal Constituents Isolated from the Metabolites of Endophytic Fungus DO14 from Dendrobium officinale. Molecules. 2016; 21:14.

86. Hideko Ikeda, Tatsuya Fukuda, Jun Yokoyama. Endophytic Fungi Associated with a Holoparasitic Plant, Balanophora japonica (Balanophoraceae). American Journal of Plant Sciences. 2016; 7:152-158

87. Noor Rahmawati, Ariesta Rakhmat Isfandito, Dea Indriani Astuti, Pingkan Aditiawati. Endophytic Fungi from Surian (Toona sinensis Roem) and Antioxidant Potency from its Culture. Asian Journal of Plant Sciences. 2016;15: 8-15

88. Paynor KA, David ES, Valentino MJG. Endophytic fungi associated with bamboo as possible sources of single cell protein using corn cob as a substrate. Mycosphere. 2016; 7(2):139-147.

89. Supeni Sufaati, Verena Agustini, Suharno. Fusarium as endophyte of some terrestrial orchid from Papua, Indonesia.Biodiversitas. 2016; 17(1): 366-371.

90. Senhua Chen, Yayue Liu, Zhaoming Liu, Runlin Cai, Yongjun Lu, Xishan Huang , Zhigang She. Isocoumarins and benzofurans from the mangrove endophytic fungus Talaromyces amestolkiae possess $\alpha$-glucosidase inhibitory and antibacterial activities. RSC Adv. 2016; 6: 26412-26420.

91. ZhouW. Eudes F. LarocheA. Identification of differentially regulated proteins in response to a compatible interaction between the pathogen Fusarium graminearum and its host, Triticum aestivum. Proteomics. 2006; 6:4599-4609.

92. Haili Li, Omar Holgui , Jianhua Wang, Tanner Schaub , Jianna Wang, Caiju Hao , Guoxia Geng. Rebecca Creamer. Proteomic analysis of the endophytic fungus Undifilum oxytropis. African Journal of Biotechnology. 2012; 11(46):10484-10493.

93. Bassett SA, Bond JJ, Kwan FY, McCulloch AF, Haynes PA, Johnson RD, Bryan GT, Jordan TW. Proteomic analysis of a filamentous fungal endophyte using EST datasets. Proteomics 2009; 9(8):2295-2300.

94. Kim Y. Nandakumar MP, MartenMR. Proteomics of filamentous fungi. Trends Biotecnology. 2007; 25:395-400. 
95. Soubhagya Kumar Bhuyan,Prasun Bandyopadhyay, Pramod Kumar Yadava. Extraction of proteins for two-dimensional gel electrophoresis and proteomic analysis from an endophytic fungus, Protocol Exchange. Scientific Reports. 2015;5.

96. Goffeau A, Barrell BG, Bussey H, Davis RW, Dujon B, Feldmann H, Galibert F, Hoheisel JD, Jacq C, Johnston M, Louis EJ, Mewes HW, Murakami Y, Philippsen P, Tettelin H, Oliver SG. Life with 6000 genes. Science. 1996; 274: 546-567.

97. Tejesvi MV, Pirttilä AM. Potential of tree endophytes as sources for new drug compounds. In: Pirttilä AM, Frank AC (eds) Endophytes of forest trees: biology and applications. Springer, New York, 2011; pp 295-312.

98. Priti V, Ramesha BT, Singh S, Ravikanth G, Ganeshaiah KN, Suryanarayanan TS, et al. How promising are endophytic fungi as alternative sources of plant secondary metabolites?. Curr. Sci. 2009; 97: 477-478.

99. Mayer AMS, Rodriguez AD, Berlinck RGS, Fusetani N. Marine pharmacology in 20072008: marine compounds with antibacterial, anticoagulant, antifungal, anti-inflammatory, antimalarial, antiprotozoal, antituberculosis, and antiviral activities; affecting the immune and nervous system, and other miscellaneous mechanisms of action. Comp Biochem Physiol C. 2011;153:191-222.

100. Selvin J, Ninawe AS, Kiran GS, Lipton AP. Sponge-microbial interactions: Ecological implications and bioprospecting avenues. Crit Rev Microbiol. 2010:36:82-90.

101. Paul Antony C, Kumaresan D, Hunger S, Drake HL, Murrell J, Shouche YS. Microbiology of Lonar Lake and other soda lake. The ISME Journal. 2013; 7: 468476.

102. Korpi A, Järnberg J, Pasanen A-L . Microbial volatile organic compounds. Crit Rev Toxicol. 2009; 39:139-193.

103. Polizzi V, Adams A, Malysheva SV, De Saeger S, Van Peteghem C,Moretti A, Picco AM, De Kimpe N. Identification of volatile markers for indoor fungal growth and chemotaxonomic classification of Aspergillus species. Fungal Biol. 2012; 116:941-953.

104. Wheatley R, Hackett C, Bruce A, Kundzewicz A. Effect of substrate composition on production of volatile organic compounds from Trichoderma spp. Inhibitory to wood decay fungi. Int Biodeterior Biodegrad. 1997; 39:199-205.

105. Stoppacher N, Kluger B, Zeilinger S, Krska R, Schuhmacher R. Identification and profiling of volatile metabolites of the biocontrol fungus Trichoderma atroviride by HS-SPMEGC-MS. J Microbiol Methods. 2010; 81:187-193.

106. Boucher HW, Talbot GH, Bradley JS, Edwards JE, Gilbert D, Rice LB, Scheld M, Spellberg B, Bartlett J. Bad bugs, no drugs: no ESKAPE! An update from the infectious diseases society of America. Clin Infect Dis. 2008;48:1-12.

107. Cars O, Hogberg LD, Murray M, Nordberg O, Sivaraman S, Lundborg CS, So AD, Tomson G. Meeting the challenge of antibiotic resistance. BMJ. 2008;3(37):a1438.

108. Spellberg B, Guidos R, Gilbert D, Bradley J, Boucher HW, Scheld WM, Bartlett JG, Edwards J. The epidemic of antibiotic-resistant infections: a call to action for the medical community from the infectious diseases society of America. Clin Infec Dis. 2008; 46:155-164.

109. Hamad B. The antibiotics market. Nat Rev Drug Discov. 2010; 9:675-676.

110. Geneva, Switzerland: W.H.O. Press. Global Tuberculosis Control: W.H.O. Report; 2011; pp. 1-246.

111. Wijeratne EM, He H, Franzblau SG, Hoffman AM, Gunatilaka AA. Phomapyrrolidones A-C, antitubercular alkaloids from the endophytic fungus Phoma sp. NRRL 46751. J Nat Prod. 2013; 76(10):1860-1865.

112. Xia G, Li J, Li H, Long Y, Lin S, Lu Y, He L, Lin Y, Liu L, She Z. Alterporrioltype dimers from the mangrove endophytic fungus, Alternaria sp. (SK11), and their MptpB inhibitions. Marine Drugs. 2014; 12(5):2953-2969.

113. Ming-Der Wu, Ming-Jen Cheng, Ih-Sheng Chen, Yung-Shun Su, Sung-Yuan Hsieh, Hsun-Shuo Chang,Chun-Wei Chang, Gwo-Fang Yuan. Phytochemical investigation of Annulohypoxylon ilanense, an endophytic fungus derived from Cinnamomum species. Chem Biodivers. 2013; 10(3):493-505.

114. Janeš D, Kreft S, Jurc M, Seme K, Štrukelj B. Antibacterial activity in higher fungi (Mushrooms) and Endophytic Fungi from Slovenia. Pharm. Biol. 2007; 45:700-706.

Braz. Arch. Biol. Technol. v.60: e17160542 Jan/Dec 2017 
115. Ding G, Song YC, Chen JR, Xu C, Ge HM. Wang XT, Tan RX, Chaetoglobosin U. A cytochalasan alkaloid from endophytic Chaetomium globosum IFB-E019. J. Nat. Prod. 2006; 69: 302-304.

116. Henrique Pereira Ramos, Glaucia Hollander Braun, Mônica Tallarico Pupo,Suraia Sai. Antimicrobial activity from endophytic fungi Arthrinium state of Apiospora montagnei Sacc. and Papulaspora immerse. Braz. arch. biol. Technol. 2010; 53(3):629-632.

117. Jianglin Zhao, Yan Mou, Tijiang Shan, Yan Li, Ligang Zhou, Mingan Wang, Jingguo Wang. Antimicrobial Metabolites from the Endophytic Fungus Pichia guilliermondii Isolated from Paris polyphylla var. yunnanensis.Molecules. 2010; 15: 7961-7970.

118. Powthong P, Jantrapanukorn B, Thongmee A, Suntornthiticharoen P. Screening of antimicrobial activities of the endophytic fungi isolated from Sesbania grandiflora (L.) Pers. J. Agr. Sci. Tech. 2013;15: 1513-1522.

119. Monali G. Desale, Bodhankar MG. Antimicrobial activity of endophytic fungi isolated from Vitex negundo Linn. Int.J.Curr.Microbiol. App.Sci. 2013; 2(12):389-395.

120. Sardul Singh Sandhu, Suneel Kumar, Ravindra Prasad Aharwa. Isolation and identification of endophytic fungi from Ricinus communis linn. and their antibacterial activity. IJRPC. 2014; 4(3), 611-618.

121. Karunai Selvi B , Balagengatharathilagam P. Isolation and screening of endophytic fungi from medicinal plants of virudhunagar district for antimicrobial activity. IJSN. 2014; 5(1): 147-155.

122. Mariana LA Vieira, Susana Johann, Frederic M. Hughes, Carlos A. Rosa, Luiz H. Rosa. The diversity and antimicrobial activity of endophytic fungi associated with medicinal plant Baccharis trimera (Asteraceae) from the Brazilian savannah. Canadian Journal of Microbiology. 2014; 60(12): 847-856.

123. Hormazabal E, Piontelli E. Endophytic fungi from Chilean native gymnosperms: Antimicrobial activity against human and phytopathogenic fungi. World J Microbiol Biotechnol. 2009; 25:813-819.

124. Zhou X, Wang Z, Jiang K, Wei Y, Lin J, Sun X, Tang K. Screening of taxol producing endophytic fungi from Taxus chinensis var. mairei. Applied Biochemistry and Microbiology. 2007; 43: 439-443.

125. Peláez F, Cabello A, Platas G, Díez MT, González del Val A, Basilio A, Martán I, Vicente F, Bills GE, Giacobbe RA, Schwartz RE, Onish JC, Meinz MS, Abruzzo GK, Flattery AM, Kong L, Kurtz MB. The discovery of enfumafungin, a novel antifungal compound produced by an endophytic Hormonema species biological activity and taxonomy of the producing organisms. Syst Appl Microbiol. 2000; 23(3):333-43.

126. Johann S, Rosa LH, Rosa CA, Perez P, Cisalpino PS, Zani CL, Cota BB. Antifungal activity of altenusin isolated from the endophytic fungus Alternaria sp. against the pathogenic fungus Paracoccidioides brasiliensis. Rev Iberoam Micol. 2012; 29(4):205-209.

127. Pimenta RS, da Silva JF, Buyer JS, Janisiewicz WJ. Endophytic fungi from plums (Prunus domestica) and their antifungal activity against Monilinia fructicola. J Food Prot. 2012; 75(10):1883-1889.

128. Guizhen Zhang, Yanhua Zhang, Jianchun Qin, Xiaoyan Qu, Jinliang Liu, Xiang Li ,Hongyu Pan. Antifungal Metabolites Produced by Chaetomium globosum No.04, an Endophytic Fungus Isolated from Ginkgo biloba. Indian J Microbiol. 2013;53(2): 175180.

129. Kumar S, Kaushik N. Endophytic fungi isolated from oil-seed crop Jatropha curcas produces oil and exhibit antifungal activity. PLoS One. 2013; 8(2):e56202.

130. Subban K, Subramani R, Johnpaul M.A novel antibacterial and antifungal phenolic compound from the endophytic fungus Pestalotiopsis mangiferae. Nat Prod Res. 2013;27(16):1445-1449.

131. Chapla VM, Zeraik ML, Leptokarydis IH, Silva GH, Bolzani VS, Young MC, Pfenning LH, Araújo AR. Antifungal compounds produced by Colletotrichum gloeosporioides, an endophytic fungus from Michelia champaca. Molecules. 2014:19(11):19243-19252. 
Novel resource and potential of endophytic fungi

132. Xiao J, Zhang Q, Gao YQ, Tang JJ, Zhang AL, Gao JM. Secondary metabolites from the endophytic Botryosphaeria dothidea of Melia azedarach and theirantifungal, antibacterial, antioxidant, and cytotoxic activities. J Agric Food Chem. 2014;62(16):35843590 .

133. Ze-Ping Luo, Hai-Yan Lin, Wen-Bing Ding, Hua-Liang He, You-Zhi L. Phylogenetic diversity and antifungal activity of endophytic fungi associated with Tephrosia purpurea. Mycobiology. 2015; 43(4):435-443.

134. Yang HR, Hu XP, Jiang CJ, Qi J, Wu YC, Li W, Zeng YJ, Li CF, Liu SX. Diversity and antimicrobial activity of endophytic fungi isolated from Cephalotaxus hainanensis Li, a well-known medicinal plant in China. Lett Appl Microbiol. 2015;61(5):484-490.

135. Indira Kalyanasundaram, Jayaprabha Nagamuthu, Srinivasan Muthukumaraswamy. Antimicrobial activity of endophytic fungi isolated and identified from salt marsh plant in Vellar Estuary. Journal of microbiology and antimicrobials. 2015;7(2): 13-20.

136. Rahul Yadav, Ajay Veer Singh, Samiksha Joshi,Manish Kumar. Antifungal and enzyme activity of endophytic fungi isolated from Ocimum sanctum and Aloe vera. African Journal of Microbiology Research. 2015; 9(29): 1783-1788.

137. Avinash KS, Ashwini HS, Ramesh Babu HN, Krishnamurthy YL. Antimicrobial potential of crude extract of Curvularia lunata, an endophytic fungi isolated from Cymbopogon caesius. Journal of Mycology. Volume 2015 (2015):Article ID 185821, 4 pages.

138. Sánchez-Ortiz BL, Sánchez-Fernández RE, Duarte G, Lappe-Oliveras P, MacíasRubalcava ML, Santiago C, Sun L, Munro MH, Santhanam J. Polyketide and benzopyran compounds of an endophytic fungus isolated from Cinnamomum mollissimum: biological activity and structure. Asian Pac J Trop Biomed. 2014; 4(8):627-632.

139. Wang M, Sun ZH, Chen YC, Liu HX, Li HH, Tan GH, Li SN, Guo XL, Zhang WM. Cytotoxic cochlioquinone derivatives from the endophytic fungus Bipolaris sorokiniana derived from Pogostemon cablin. Fitoterapia. 2016. doi: 10.1016/j.fitote.2016.02.005.

140. Silva-Hughes AF, Wedge DE, Cantrell CL, Carvalho CR, Pan Z, Moraes RM, Madoxx VL, Rosa LH. Diversity and antifungal activity of the endophytic fungi associated with the native medicinal cactus Opuntia humifusa (Cactaceae) from the United States. Microbiol Res. 2015; 175:67-77.

141. Bashyal BP, Wellensiek BP, Ramakrishnan R, Faeth SH, Ahmad N, Gunatilaka AA. Altertoxins with potent anti-HIV activity from Alternaria tenuissima QUE1Se, a fungal endophyte of Quercus emoryi. Bioorg Med Chem. 2014;22(21):6112-6116.

142. Brian P. Wellensiek, Rajesh Ramakrishnan, Bharat P. Bashyal, Yvette Eason, A. A. Leslie Gunatilaka, Nafees Ahmad. Inhibition of HIV-1 Replication by Secondary Metabolites from Endophytic Fungi of Desert Plants. Open Virol J. 2013; 7: 72-80.

143. Zhang G, Sun S, Zhu T, Lin Z, Gu J, Li D, Gu Q. Antiviral isoindolone derivatives from an endophytic fungus Emericella sp. associated with Aegiceras corniculatum. Phytochemistry. 2011;72(11-12):1436-1442.

144. ChannabasavaMelappa Govindappa. First report of anticancer agent, lapachol producing endophyte Aspergillus niger of Tabebuia argentea and its In vitro cytotoxicity assays. Bangladesh J Pharmacol. 2014;9: 129-139

145. Souwalak Phongpaichit, Jaru Nikom, Nattawut Rungjindamai, Jariya Sakayaroj, Nongporn Hutadilok-Towatana, Vatcharin Rukachaisirikul, Kanyawim Kirtikara..Biological activities of extracts from endophytic fungi isolated from Garcinia plants. FEMS Immunol Med Microbiol. 2007; 51: 517-525.

146. Suthep Wiyakrutta, Nongluksna Sriubolmas, Wattana Panphut,Nuntawan Thong on,Kannawat Danwisetkanjana, Nijsiri Ruangrungsi, Vithaya Meevootisom. Endophytic fungi with anti-microbial, anti-cancer and anti-malarial activities isolated from Thai medicinal plants. World Journal of Microbiology and Biotechnology. 2004; 20(3):pp 265272.

147. Kala CP. Status and conservation of rare and endangered medicinal plants in the Indian trans-Himalaya. Biol Conserv. 2000; 93. 371-379.

Braz. Arch. Biol. Technol. v.60: e17160542 Jan/Dec 2017 
148.

Kharwar RN, Mishra A, Gond SK, et al. Anticancer compounds derived from fungal endophytes: their importance and future challenges. Nat Prod Rep. 2011; 28:12081228 .

149.

Ling Chen, Qiao-Yan Zhang, Min Jia, Qian-Liang Ming, Wei Yue, Khalid Rahman, Lu-Ping Qin, Ting Han. Endophytic fungi with antitumor activities: Their occurrence and anticancer compounds. Crit Rev Microbiol. 2014;24:1-20.

150. Teles HL, Sordi R, Silva GH, Castro-Gamboa I, Bolzani Vda S, Pfenning LH, de Abreu LM, Costa-Neto CM, Young MC, Araújo AR. Aromatic compounds produced by Periconia atropurpurea, an endophytic fungus associated with Xylopia aromatic. Phytochemistry. 2006; 67(24):2686-2690.

151. Ge HM, Yu ZG, Zhang J, Wu JH, Tan RX. Bioactive alkaloids from endophytic Aspergillus fumigates. J Nat Prod. 2009; 72(4):753-755.

152. Gangadevi V, Muthumary J. Taxol production by Pestalotiopsis terminaliae, an endophytic fungus of Terminalia arjuna (arjun tree). Biotechnol Appl Biochem. 2009;52:9-15.

153. Pandi M, Manikandan R, Muthumary J. Anticancer activity of fungal taxol derived from Botryodiplodia theobromae Pat, an endophytic fungus, against 7, 12 dimethyl benz(a)anthracene (DMBA)-induced mammary gland carcinogenesis in Sprague dawley rats. Biomedicine and pharmacotherapy. 2010; 64(1): 48-53.

154. Jin-long Cui, Shun-xing Guo, Pei-gen Xiao. Antitumor and antimicrobial activities of endophytic fungi from medicinal parts of Aquilaria sinensis. J Zhejiang Univ Sci B. 2011;12(5): 385-392.

155. Giridharan P, Verekar SA, Khanna A, Mishra PD, Deshmukh SK. Anticancer activity of sclerotiorin, isolated from an endophytic fungus Cephalotheca faveolata Yaguchi, Nishim. and Udagawa. Indian J Exp Bio. 2012; 50(7):464-468.

156. Wang FW. Bioactive metabolites from Guignardia sp., an endophytic fungus residing in Undaria pinnatifida. Chin J Nat Med. 2012;10(1):72-76.

157. Azizollah Ebrahimia, Shirin Asghariana, Saied Habibian. Antimicrobial activities of isolated endophytes from Some Iranian Native Medicinal Plants. Iranian Journal of Pharmaceutical Sciences. 2010; 6(3):217-222.

158. Jayashree Lakshmi P,Vanmathi Selvi K. Anticancer potentials of secondary metabolites from endophytes of Barringtonia acutangula and its molecular characterization. Int.J.Curr.Microbiol.App.Sci. 2013;2(2):44-45.

159. Xu YM, Espinosa-Artiles P, Liu MX, Arnold AE, Gunatilaka AA.. Secoemestrin D, a cytotoxic epitetrathiodioxopiperizine, and emericellenes A-E, five sesterterpenoids from Emericella sp. AST0036, a fungal endophyte of Astragalus lentiginosus1. J Nat Prod. 2013; 76(12):2330-2336.

160. Lai D, Brötz-Oesterhelt H, Müller WE, Wray V, Proksch P. Bioactive polyketides and alkaloids from Penicillium citrinum, a fungal endophyte isolated from Ocimum tenuiflorum. Fitoterapia. 2013; 91:100-106.

161. Mohana Kumara P, Zuehlke S, Priti V, Ramesha BT, Shweta S, Ravikanth G, Vasudeva R, Santhoshkumar TR, Spiteller M, Uma Shaanker R. Fusarium proliferatum, an endophytic fungus from Dysoxylum binectariferum Hook.f, produces rohitukine, a chromane alkaloid possessing anti-cancer activity.Antonie Van Leeuwenhoek. 2012;101(2):323-329.

162. Carolina Santiago, Lin Sun, Murray Herbert Gibson Munro, Jacinta Santhanam. Polyketide and benzopyran compounds of an endophytic fungus isolated from Cinnamomum mollissimum: biological activity and structure. Asian Pac J Trop Biomed. 2014; 4(8): 627-632.

163. Qian YX, Kang JC, Lei BX, Wang L, Huang Y.Screening and taxonomic identification of endophytic fungi with antitumor and antioxidant activities from Artemisia lactiflora. Zhongguo Zhong Yao Za Zhi. 2014; 39(3):438-441.

164. Lin T, Wang G, Shan W, Zeng D, Ding R, Jiang X, Zhu D, Liu X, Yang S, Chen H. Myrotheciumones: bicyclic cytotoxic lactones isolated from an endophytic fungus of Ajuga decumbens. Bioorg Med Chem Lett. 2014; 24(11):2504-2507

165. Katoch M, Singh G, Sharma S, Gupta N, Sangwan PL, Saxena AK. Cytotoxic and antimicrobial activities of endophytic fungi isolated from Bacopa monnieri (L.) Pennell (Scrophulariaceae). BMC Complement. Altern Med. 2014; 14:52. 
Novel resource and potential of endophytic fungi

166. Shilpa Amit Verekar, Prabhu Dutt Mishra, Eyyammadichiyil Sankaranarayanan Sreekumar, Sunil Kumar Deshmukh, Heinz-Herbert Fiebig, Gerhard Kelter, Armin Maier.Anticancer activity of new depsipeptide compound isolated from an endophytic fungus. The Journal of Antibiotics. 2014; 67.697-701.

167. Yougen Wu, Sisay Girmay, Vitor Martins da Silva, Brian Perry, Xinwen $\mathrm{Hu}$, Ghee T. Tan. The Role of Endophytic Fungi in the Anticancer Activity of Morinda citrifolia Linn. (Noni). Evidence Based Complementary and Alternative Medicine. 2015; Article ID 393960, 8 pages.

168. Palem PP, Kuriakose GC, Jayabaskaran C..An Endophytic Fungus, Talaromyces radicus Isolated from Catharanthus roseus, Produces Vincristine and Vinblastine, Which Induce Apoptotic Cell Death. PLoS One. 2015;10(12):e0144476.

169. Puri SC, Amna T, Khajuria A, Gupta A, Arora R, Spiteller M, Qazi GN. Immunomodulatory activity of an extract of the novel fungal endophyte Entrophospora infrequens isolated from Nothapodytes foetida (Wight) Sleumer. Acta Microbiol Immunol Hung. 2007; 54(3):237-60.

170. Kumar DS, Lau CS, Wan JM, Yang D, Hyde KD. Immunomodulatory compounds from Pestalotiopsis leucothës, an endophytic fungus from Tripterygium wilfordii. Life Sci. 2005; 78(2):147-56.

171. Siva Sundara Kumar D, Cheung HY, Lau CS, Chen F, Hyde KD. In vitro studies of endophytic fungi from Tripterygium wilfordii with anti-proliferative activity on human peripheral blood mononuclear cells. J Ethnopharmacol. 2004; 94(2-3):295-300.

172. Smita Madagundi, Prasanna Habbujagadish K S , Sunil Shukla , Manjunath Salagare, Venkatrao Kulkarni. Free radical scavenging and in vitro immunomodulatory activities of endophytic fungi of Ocimum sanctum Linn. Farmacia. 2013; 61(2);330-343.

173. Strobel GA, Pliam NB. Immunosuppressant diterpene compound. U.S. Patent No. 5, 1997;648:376.

174. Strobel GA, Hess WM, Ford E, Sidhu RS, Yang, X. Taxol from fungal endophyte and issue of biodiversity. Journal of Industrial Microbiology. 1996; 17: 417-423.

175. Wani MC, Taylor HL, Wall ME, Coggon P, McPhail A. Plant antitumor agents. VI. The isolation and structure of Taxol, a novel antileukemic and antitumor agent from Taxus brevifolia. J. Am. Chem. Soc. 1971;93: 2325-2327.

176. Ushasri R, Anusha R. In vitro anti-diabetic activity of ethanolic and acetone extracts of endophytic fungi Syncephalastrum racemosum isolated from the seaweed Gracilaria corticata by alpha-amylase inhibition assay method. Int.J.Curr.Microbiol.App.Sci. 2015; 4(1): 254-259.

177. Dhankhar S, Dhankhar S, Yadav JP. Investigations towards new antidiabetic drugs from fungal endophytes associated with Salvadora oleoides Decne. Med Chem. 2013; 9(4):624-632.

178. Prabavathy D, Valli nachiyar C. Antimicrobial and antidiabetic activity of an endophytic fungi isolated from Adathoda beddomei. International Journal of Pharmacy and Pharmaceutical Sciences.2013;5(3):780-783.

179. Singh B, Kaur A. Antidiabetic potential of a peptide isolated from an endophytic Aspergillus awamori. 2016; 120(2): 301-311.

180. Govindappa M, Sadananda TS, Channabasava, Ramachandra YL, Chandrappa $\mathrm{CP}$, Padmalatha RS, Prasad SK. In vitro and in vivo antidiabetic activity of lectin $(\mathrm{N}$ acetylgalactosamine, $64 \mathrm{kDa}$ ) isolated from endophytic fungi, Alternaria species from Viscum album on alloxan induced diabetic rats. Integr Obesity Diabetes. 2015; 1(1): 1119.

181. Artanti N, Tachibana S, Kardono LB, Sukiman H. Screening of endophytic fungi having ability for antioxidative and alpha-glucosidase inhibitor activities isolated from Taxus sumatrana. Pakistan Journal of Biological Sciences. 2011;14(22):1019-1023.

182. Gülçin I. Comparison of in vitro antioxidant and antiradical activities of Ltyrosine and L-Dopa. Amino acids 2007; 32(3): 431- 438.

183. AruomaOI. Free radical, oxidative stress, and antioxidants in human health and disease. Journal of the American oil chemists society. 1998;75:199-212. 
184. Manila Yadav, Amita Yadav, Jaya Parkash Yadav. In vitro antioxidant activity and total phenolic content of endophytic fungi isolated from Eugenia jambolana Lam. Asian Pacific Journal of Tropical Medicine. 2014; 7(1): S256-S261.

185. Strobel G, Ford E, Worapong J, Harper JK, Arif AM, Grant DM, et al. Isopestacin, a unique isobenzofuranone from Pestalotiopsis microspora possessing antifungal and antioxidant properties. Phytochemistry. 2002; 60(2): 179-183.

186. Seema dhankhar, Sandeep kumar, Sandeep dhankhar, Jaya parkash yadav. antioxidant activity of fungal endophytes isolated from Salvadora oleoides decne. Int $\mathbf{J}$ Pharm Pharm Sci. 2012; 4(2): 380-385.

187. Srinivasan K, Jagadish LK, Shenbhagaraman R, Muthumary J.Antioxidant activity of endophytic fungus Phyllosticta sp. isolated from Guazuma tomentosa. Journal of Phytology. 2010; 2(6): 37-41.

188. Zeng PY, Wu1 JG, Liao LM, Chen T.Q, Wu JZ, Wong K-H. In vitro antioxidant activities of endophytic fungi isolated from the liverwort Scapania verrucosa. Genetics and Molecular Research. 2011;10 (4): 3169-3179.

189. Jin-Long Cui,Ting-Ting Guo,Zhen-Xing Ren,Na-Sha Zhang,Meng-Liang Wang, Diversity and antioxidant activity of culturable endophytic fungi from alpine plants of Rhodiola crenulata, R. angusta, and R. sachalinensis. PLoS One. 2015; 10(3): e0118204. doi:10.1371/journal.pone.0118204.

190. Govindappa M, Channabasava R, Sunil Kumar K. R., Pushpalatha KC. Antioxidant activity and phytochemical screening of crude endophytes extracts of Tabebuia argentea Bur. \& K. Sch. American Journal of Plant Sciences. 2013; 4:16411652.

191. Elfita, Muharni, Munawar, Rizki. Isolation of Antioxidant Compound from Endophytic Fungi Acremonium sp. from the Twigs of Kandis Gajah. Makara Journal of Science. 2012; 16(1): 46-50.

192. Manjusha Choudhary, Vipin Kumar, Hitesh Malhotra, Surender Singh. Medicinal plants with potential anti-arthritic activity. J Intercult Ethnopharmacol. 2015; 4(2): 147-179.

193. Pretsch A, Nagl M, Schwendinger K, Kreiseder B, Wiederstein M, Pretsch D, et al. Antimicrobial and Anti-Inflammatory Activities of Endophytic Fungi Talaromyces wortmannii extracts against Acne-Inducing Bacteria. PLoS One. 2014; 9(6): e97929. doi:10.1371/journal.pone.0097929.

194. Meet Shah,Sunil Kumar Deshmukh,Shilpa A. Verekar,Akash Gohil,Abhijeet S. Kate,V. Rekha, Asha Kulkarni-Almeida, Anti-inflammatory properties of mutolide isolated from the fungus Lepidosphaeria species (PM0651419), SpringerPlus.2015; 4:706.

195. Sunil Kumar Deshmukh, Prabhu Dutt Mishra, Asha Kulkarni-Almeida, Shilpa Verekar, Manas Ranjan Sahoo, Giridharan Periyasamy, Hitesh Goswami, Amit Khanna, Arun Balakrishnan, Ram Vishwakarma. Anti-Inflammatory and anticancer activity of argoflavin isolated from an endophytic fungus. Chemistry \& Biodiversity. 2009; 6: 784789. 